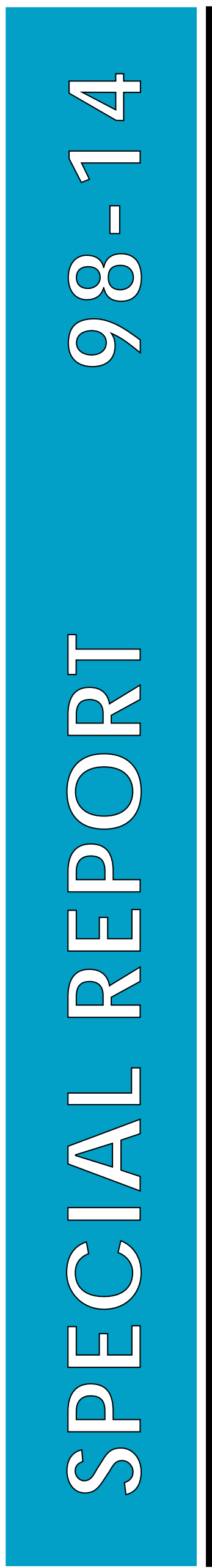

\title{
Nonstructural Ice Control
}

Robert B. Haehnel

December 1998 
Abstract: Nonstructural ice control measures are used for reducing the frequency and severity of ice jam damages that do not rely on the use of a structure placed in the river. This report is a comprehensive review of current nonstructural ice control methods in use. Both advance measures and emergency response methods are addressed. Where possible, the effectiveness of these methods has been assessed, and cost of application has been tabulated. In terms of development, some of these are still in their infancy, while others are well advanced in terms of available guidance and field experience. Nonstructural methods can be used to extend the operating envelope of structural measures and can play a role in an ice control strategy that uses both structural and nonstructural components to provide the desired results. There is little guidance currenty available to predict the reduction in ice jam potential due to application of any of these measures. Further work in this area should focus on developing governing relationships that relate ice and river properties and meteorological conditions to ice jam potential and severity.

How to get copies of CRREL technical publications:

Department of Defense personnel and contractors may order reports through the Defense Technical Information Center: DTIC-BR SUITE 0944

8725 J OHN J KINGMAN RD

FT BELVOIR VA 22060-6218

Telephone 18002253842

E-mail_help@dtic.mil msorders@dtic.mil

WWW http://www.dtic.dla.mil/

All others may order reports through the National Technical Information Service:

NTIS

5285 PORT ROYAL RD

SPRINGFIELD VA 22161

Telephone 17034874650

17034874639 (TDD for the hearing-impaired)

E-mail_orders@ntis.fedworld.gov

WWW http://www.fedworld.gov/ntis/ntishome.html

A complete list of all CRREL technical publications is available from:

USACRREL (CECRL-IB)

72 LYME RD

HANOVER NH 03755-1290

Telephone 16036464338

E-mail_techpubs@crrel.usace.army.mil

For information on all aspects of the Cold Regions Research and Engineering Laboratory, visit our World Wide Web site: http://www.crrel.usace.army.mil 


\section{Special Report 98-14}

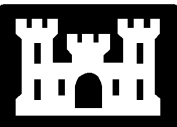

US Army Corps

of Engineers $₫$

Cold Regions Research \&

Engineering Laboratory

\section{Nonstructural Ice Control}

Robert B. Haehnel

December 1998 


\section{PREFACE}

This report was prepared by Robert B. Haehnel, Research Mechanical Engineer, Ice Engineering Research Division, Applied Science and Technology Directorate, U. S. Army Cold Regions Research and Engineering Laboratory. Funding for this research was provided under Work Unit CWIS 33137, Ice Mitigation for Navigable Rivers, of the U.S. Army Corps of Engineers Civil Works Cold Regions Engineering Program.

The author thanks Andrew Tuthill and Steven Daly for technically reviewing the manuscript of this report.

The contents of this report are not to be used for advertising or promotional purposes. Citation of brand names does not constitute an official endorsement or approval of the use of such commercial products. 


\section{CONTENTS}

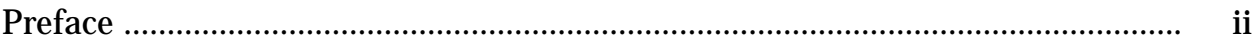

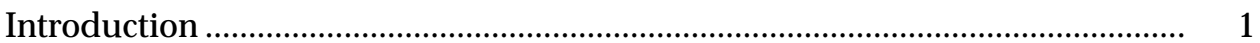

Measures to reduce the risk of ice jam formation ................................................ 1

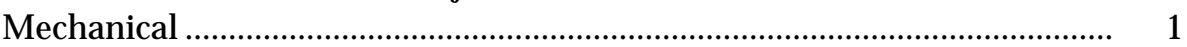

Ice cutting ................................................................................................

Hole cutting ……................................................................................... 7

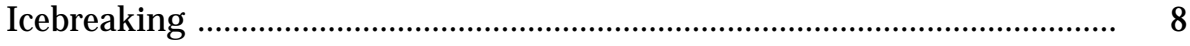

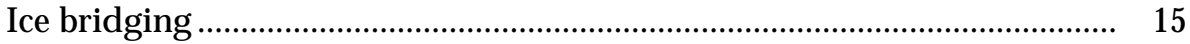

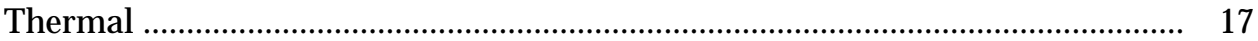

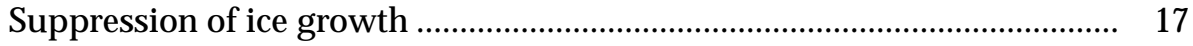

Routing of warm water .......................................................................... 18

Increasing solar absorption .................................................................. 20

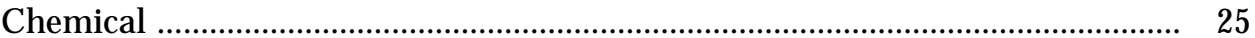

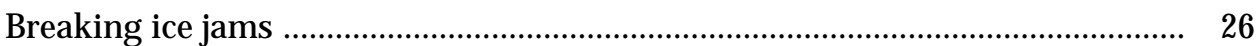

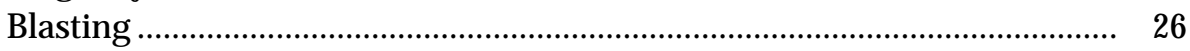

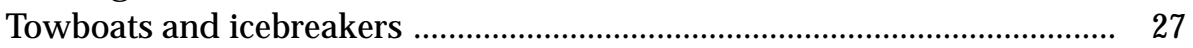

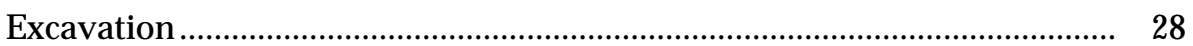

Cost and performance of nonstructural measures ............................................... 29

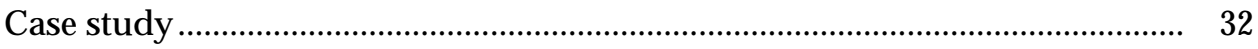

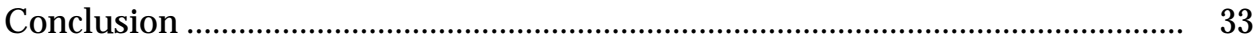

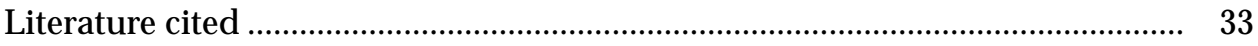

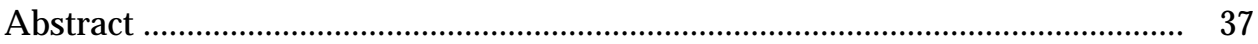

\section{ILLUSTRATIONS}

Figure Page

1. Trench patterns cut in river ice ................................................................ 2

2. Trenching equipment ................................................................................ 4

3. ICESAW used for cutting river ice ....................................................................... 5

4. Ice channeling plow developed by Tyskin ........................................................... 5

5. Hole drilling operations on the Oconto River at Oconto, Wisconsin ...................... 7

6. Equipment used for drilling holes in the Oconto River .......................................... 8

7. Holes drilled in the Oconto River ice cover at the upstream end of Ajax Island

8. Typical observed ice profile around a hole drilled in ice with water

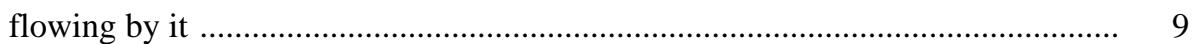

9. Tow with a raked barge used for breaking river ice ............................................... 11

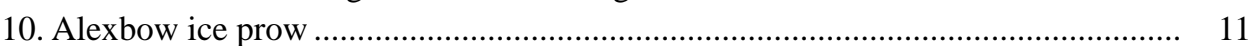

11. Using a bucket dredge to break ice in a river .................................................... 13

12. Breaking ice with an amphibious excavator on the Aroostook River,

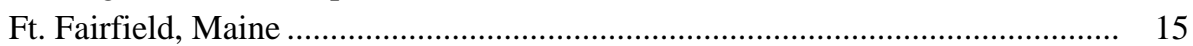

13. Examples of ice bridging ............................................................................ 16

14. Various sources of thermal energy available for deteriorating and melting an ice cover 
15. Siphons used to route warm water from the Dresden Power Station Cooling Pond for melting ice in the Kankakee River,

Wilmington, Illinois ................................................................................. 19

16. Schematic of a typical bubbler system ............................................................. 20

17. Albedo as a function of application density for Ottawa Valley crushed limestone applied to an ice surface ……................................................ 22

18. Equipment used for dusting ......................................................................... 24

19. Breaching an ice jam in Hardwick, Vermont, using excavation equipment working from the shore and a bridge ............................................. 28

20. Cost and performance data for various methods of ice control ............................. 31

\section{TABLES}

Table

1. Average albedo values of various surfaces and dusting materials ......................... 21

2. Eutectic temperatures and volume of ice melted for various salts ....................... 26

3. Cost and performance of ice cutting equipment .................................................. 29

4. Cost and performance of icebreaking methods ................................................. 30

5. Cost of dusting operations in 1996 U.S. dollars ................................................... 31 


\title{
Nonstructural Ice Control
}

\author{
ROBERT B. HAEHNEL
}

\section{INTRODUCTION}

Nonstructural ice control encompasses methods used for reducing the frequency and severity of damages from ice jams without use of a structure placed in the river. These were the first measures employed to prevent and breakup ice jams. For example, as early as 1758 blasting was used in Germany to remove ice jams (Van der Kley 1965), and icebreaking vessels were used to break river ice starting in the 1880s (Bolsenga 1968). The attraction of nonstructural ice control methods is that they are generally inexpensive and can be applied using readily available equipment and supplies (e.g., chainsaws, trenchers, cropdusters, etc.). Also these methods are popular because of the perception that they can be applied on short notice; of course, the best results are obtained with advance planning, because obtaining the necessary permits and equipment, and training of personnel requires a considerable amount of time. Furthermore, the basic concept of not placing a structure into the river has appeal, since it does not create an obstacle for navigation, restrict recreational activity, or change stream habitat.

This report brings together in one place the nonstructural ice control experience that has been developed and used worldwide. Most of the work that has been done in this area has concentrated on weakening or destroying the ice cover in advance of ice jam formation. However, some nonstructural methods have been used to breach ice jams. As such, this report is broken into two sections, the first dealing with advance measures, and the second addresses ice jam breaking methods (or expedient measures). Examples of each method are provided along with guidance for applying the method to a specific site. Additionally, the cost, performance, and range of applicability for the various methods are discussed.

\section{MEASURES TO REDUCE THE RISK OF ICE JAM FORMATION}

At locations that frequently experience ice jam flooding, measures can be applied in advance to reduce or eliminate the risk of ice jam formation. Most often these methods are targeted at weakening, breaking, or eliminating the ice in the problem reach. For example, at a river confluence, stable ice that has formed in the main stem may block ice released from the tributary, thereby initiating an ice jam at the confluence. In this case weakening or removing the ice in the main stem may reduce the likelihood of a jam forming at the confluence.

There are three basic mechanisms that have been used for weakening or destroying ice: mechanical, thermal, and chemical. These may be used separately or in concert to provide the desired result.

\section{Mechanical}

Generally mechanical measures focus on weakening or removing the ice cover through machining or fracturing the ice so that the remaining cover has little or no structural integrity. Subsequently the ice may be left in place to melt, removed by natural river flow, or conveyed out of the river via another mechanical system. Below is a summary of the various mechanical measures used.

\section{Ice cutting}

It is unclear when the cutting of river ice to reduce ice jam threat first started. The earliest efforts employed the same equipment that was used originally for harvesting ice for refrigeration. More recently the blocks were cut using gas-enginedriven circular saws (Oconto County Reporter 1952, Deugo 1973). The intent of ice cutting is to hasten the release of ice in jam-prone river reaches such 
as bends, slope changes, or confluences. An approach frequently used is to cut the ice free from the banks and cut crossing patterns in the ice so that it breaks into pieces that are half the river width or less (Jolicoeur et al. 1984). The efficiency and efficacy of cutting ice have improved with the advent of modern mining and ditch digging equipment. The details of cutter design are beyond the scope of this work. The focus will therefore be on the performance of available cutting machinery, such as cutting rates, and the effectiveness of various ice cutting strategies for preventing or mitigating ice jam formation.

Aleinikov et al. (1974) explored the use of cut- ting ice to prevent ice jam formation at the confluence of a river and the reservoir of a hydroelectric dam in Siberia. The river width in this reach was $180-230 \mathrm{~m}$. The cutting operation was started about 1 month prior to normal breakup. First, a 7-km slot was cut in the 1- to 1.2-m thick ice at the center line of the channel, starting from the upstream end of the backwater and proceeding downstream to within $500 \mathrm{~m}$ of the downstream edge of the reservoir ice cover. Then, transverse slots were cut almost bank to bank at a spacing of 30-60 m. Finally, discontinuous slots were cut along both banks. This pattern yielded rectangular ice pieces that were about half of the

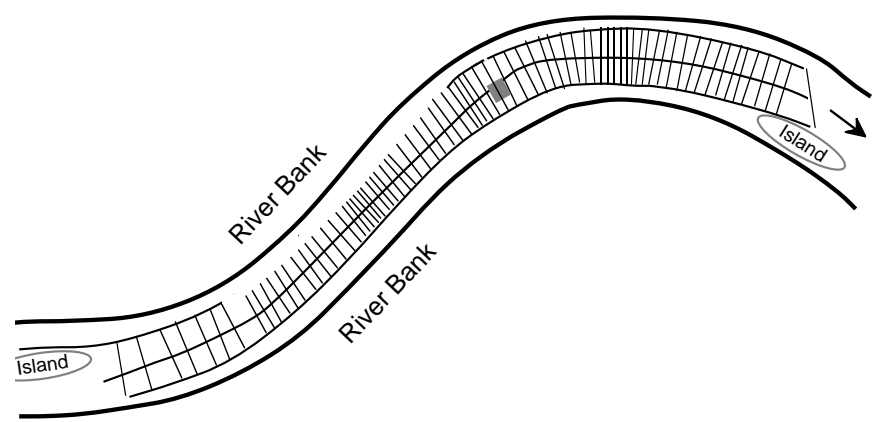

a. Slots cut in a backwater to a Siberian hydroelectric reservoir (after Aleinikov et al. 1974).

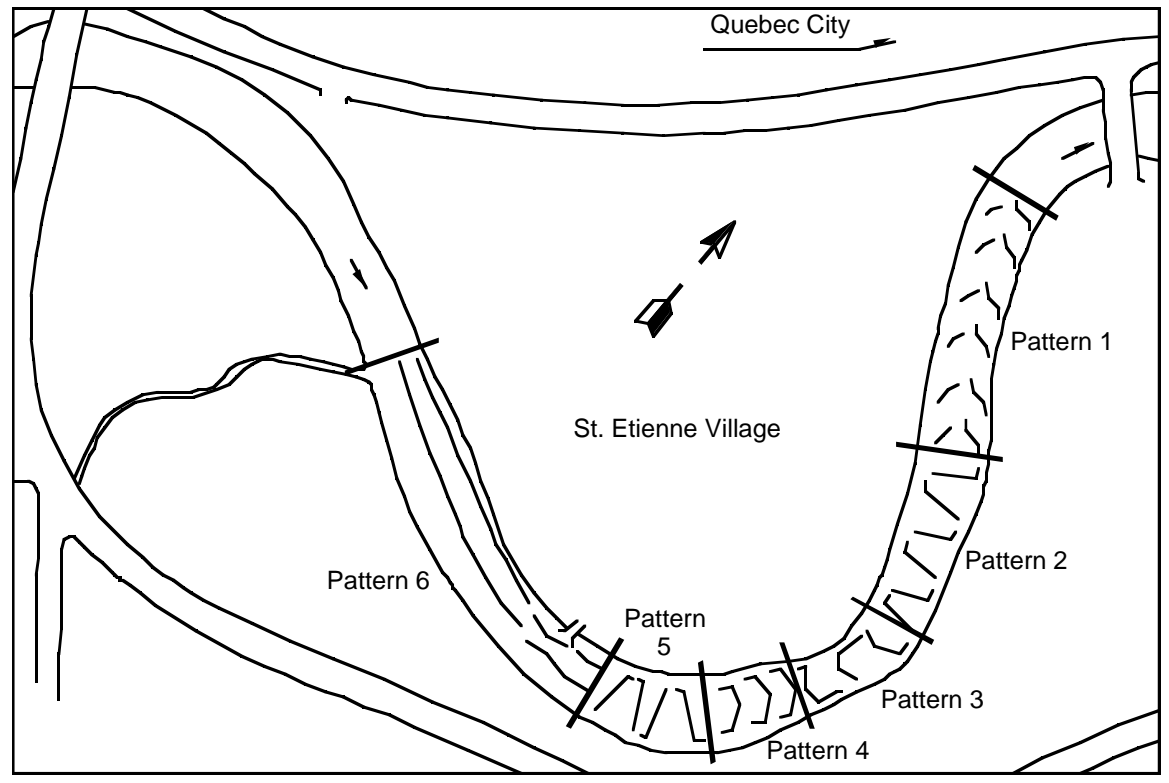

b. Patterns cut on the Beaurivarge River, Canada (after Jolicoeur et al. 1984).

Figure 1. Trench patterns cut in river ice. 
river width long and about a quarter or less of the river width wide (Fig. 1a). The transverse slots did not connect to the slots along the bank, which prevented the ice from moving during the cutting operation. About 10 days after the cutting operation was completed, the water in the reservoir was drawn down $1 \mathrm{~m}$ to break up the remaining tendons of ice. Then just before a forecasted ice breakup event, the reservoir level was returned to the normal pool elevation. This operation was successful at causing the ice in the problem reach to release 1-2 days before breakup of the upstream ice. Consequently, the upstream ice was deposited into an ice-free reservoir, rather than jamming at the head of the backwater. In 1972 the ice released 15 hours prior to the spring ice run, while in 1973 it released two days prior.

Jolicoeur et al. (1984) examined the use of various trenching patterns in a river meander to prevent ice jam formation, and several patterns were tried that spanned the 36-m river width (Fig. 1b). The test reach was approximately $600 \mathrm{~m}$ long. Roughly any pattern that crosses from bank to bank was effective, though the herringbone pattern (pattern 1) broke into the smallest ice pieces. In contrast, simply cutting slots parallel to the bank (pattern 6) did not assure breakup of the ice cover. The resulting long, thin ice floes moved intact into the river bend and halted there.

In Finland an extensive ice cutting operation is carried out annually on rivers and lakes to reduce ice jam flooding and damages associated with spring breakup. The cutting operation is done $2-3$ weeks prior to the anticipated spring runoff period. Generally the ice is cut to within $10 \mathrm{~cm}$ or so of its full thickness, leaving the ice cover semi-intact. This remaining ice melts out and easily breaks up during the subsequent warm weather and rising water. On rivers, slots are cut along each bank. In bends the ice is also cut in a herringbone pattern across the full river width. On lakes, large sections of the ice near the river mouth are cut into herringbone patterns to allow sections of the lake ice cover to collapse upon arrival of the surge of water and ice from the source river. On one lake inlet, a 300-mwide $\times 10-\mathrm{km}$-long section of the ice cover was cut to allow storage for ice from the feeding river*.

Ice cutting requires deployment of personnel and equipment onto the ice cover, so unless amphibious vehicles are used, the trenches need to be cut while the ice is still thick and strong. This

*Personnel communication, M. G. Ferrick, CRREL, 1997. usually requires the operation be carried out about a month prior to the expected ice breakup period, when the probability for ice release is still very low. The width of the slot must be sufficient to prevent freeze back. Usually widths of $10-15 \mathrm{~cm}$ are adequate.

The type of equipment used to cut ice is a major consideration in such an operation. Some of the types of machinery used to cut ice include trenchers, ice plows, water jet and thermal cutters, and specially designed amphibious cutters.

\section{Trenchers}

Trenchers are customarily used for digging ditches in soil for laying cable and piping (Fig. 2). Several types of these have been used without modification. Cutting depths range from 0.6 to 1.2 $\mathrm{m}$ and trench widths typically vary from 10 to 15 $\mathrm{cm}$. Equipment varies in weight from small walkbehind trenchers $(300 \mathrm{~kg})$ to four-wheel-drive and tracked trenchers $(2,000$ to over $10,000 \mathrm{~kg})$. The choice of the trencher will depend on the thickness and bearing capacity of the ice cover. Jolicoeur et al. (1984) used a Case ${ }^{\mathrm{TM}} \mathrm{DH} 4$ trencher that weighs about $2600 \mathrm{~kg}$ and has a cutter width of 15 $\mathrm{cm}$. This four-wheel- drive trencher travels easily on ice that is covered by up to $30 \mathrm{~cm}$ of snow, and it cut $50 \mathrm{~cm}$ of ice at a speed of up to $8 \mathrm{~m} / \mathrm{min}$. This trencher took about 8 hours to cut all of the patterns shown in Figure 1b.

During the spring of 1994 a walk-behind, selfpropelled Ditchwitch ${ }^{\mathrm{TM}} 1620$ trencher was used at Montpelier, Vermont (Fig. 2b). This model features a hydraulically actuated cutting boom that reduced the effort to start a cut in the sheet ice and retract the cutting boom from the trench. The cutting boom was fitted with a carbide toothed Shark Chain ${ }^{\mathrm{TM}}$, which is designed for cutting hard, rocky, and frosted ground. The 1620 weighs about 600 $\mathrm{kg}$ and has a cutter width of $10 \mathrm{~cm}$ (kerf width of about $12 \mathrm{~cm}$ ). Even with tire chains this trencher could not propel itself through the $15 \mathrm{~cm}$ of snow on the ice cover, so a path for the trencher was cleared in the snow using a snowblower. This operation required about $12-16$ hours to cut approximately 1 lineal kilometer of trenches in the ice.

\section{Special design trenching equipment}

The ice cutting operation on the Siberian reservoir described earlier was accomplished using a specially built trencher developed by Gorki Polytechnic Institute (GPI) (Aleinikov et al. 1974). This 86-kW, 4300-kg amphibious vehicle was propelled by a twin Archimedean screw drive. The two 


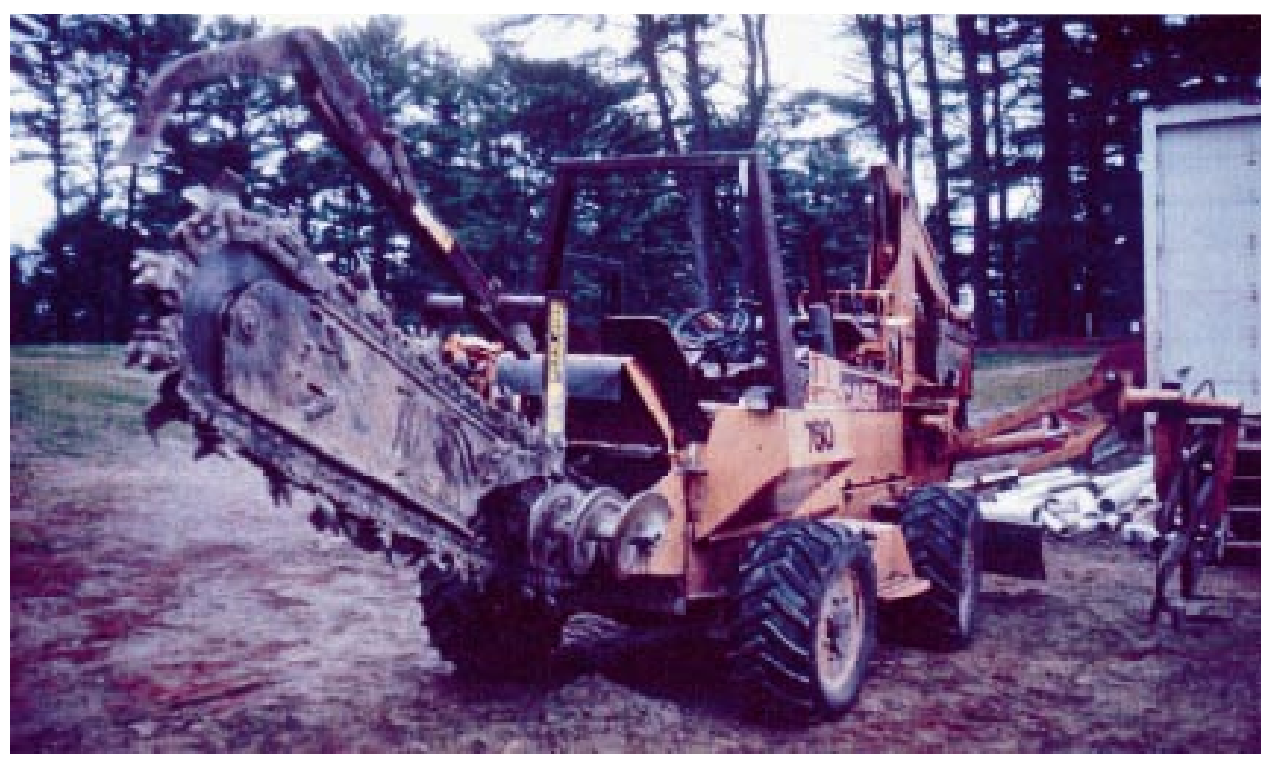

a. Case 750.

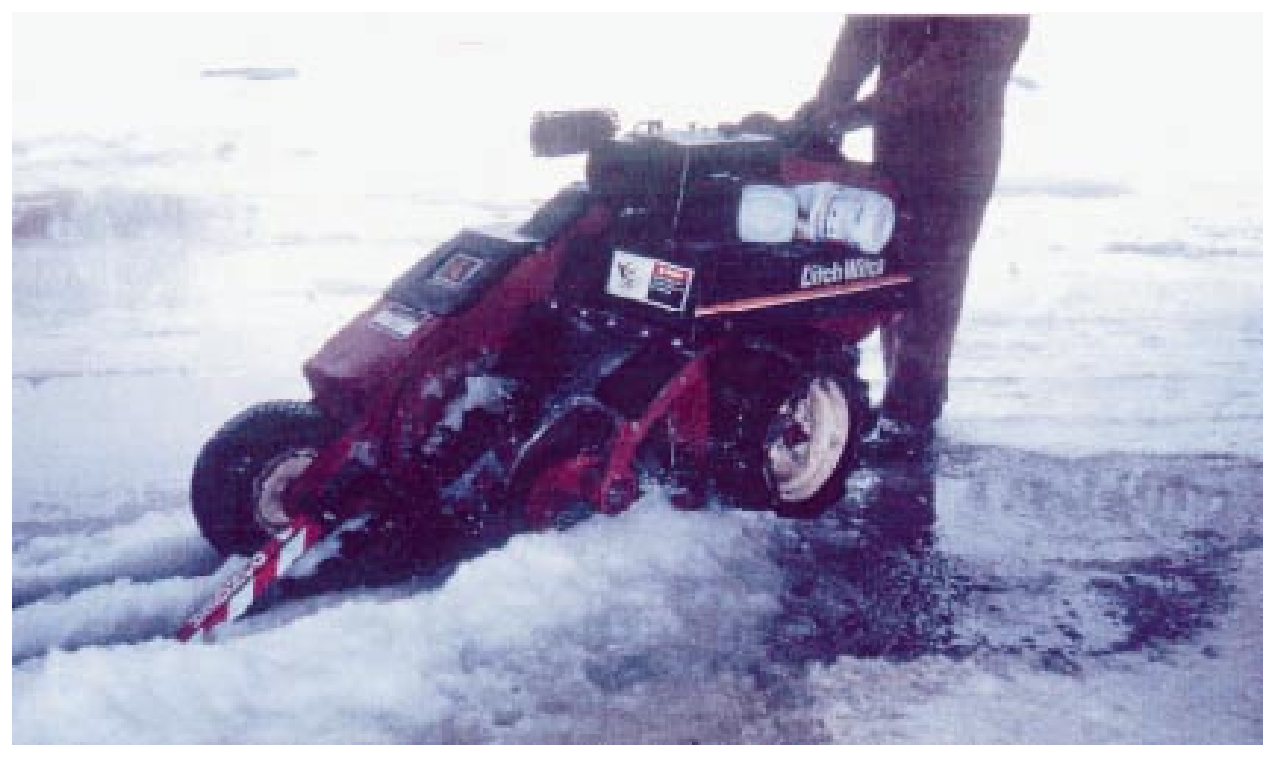

b. Ditchwitch 1260 cutting ice in Montpelier, Vermont.

Figure 2. Trenching equipment.

screws were large, tapered cylindrical pontoons with helixes on the outside. The screws were mounted one on either side of the chassis, giving the vehicle the appearance of a small pontoon boat, with the screws providing flotation if necessary. Forward propulsion was achieved by rotating the screws in unison. Turning was achieved-as with tracked vehicles-using skid steer. The vehicle cut $0.6-0.8 \mathrm{~cm}$ ice at about $0.15-0.21 \mathrm{~km} / \mathrm{hr}$.

The ICESAW-a 168-kW, 8-ton tracked am- phibious vehicle built by Mobimar Ltd. in Finland (Fig. 3) - was developed in cooperation with the Finnish government to help reduce ice jam flooding. ${ }^{*}$ It was developed to replace more costly methods, such as icebreaking, blasting, and dusting.t

*Personal communication, R. Gronqvist, Mobimar, Ltd., Turku, Finland, 10 May 1994.

tPersonal communication, E. Mykkanen, Finnish Environment Agency, Kokkola, Finland, 22 June 1997. 


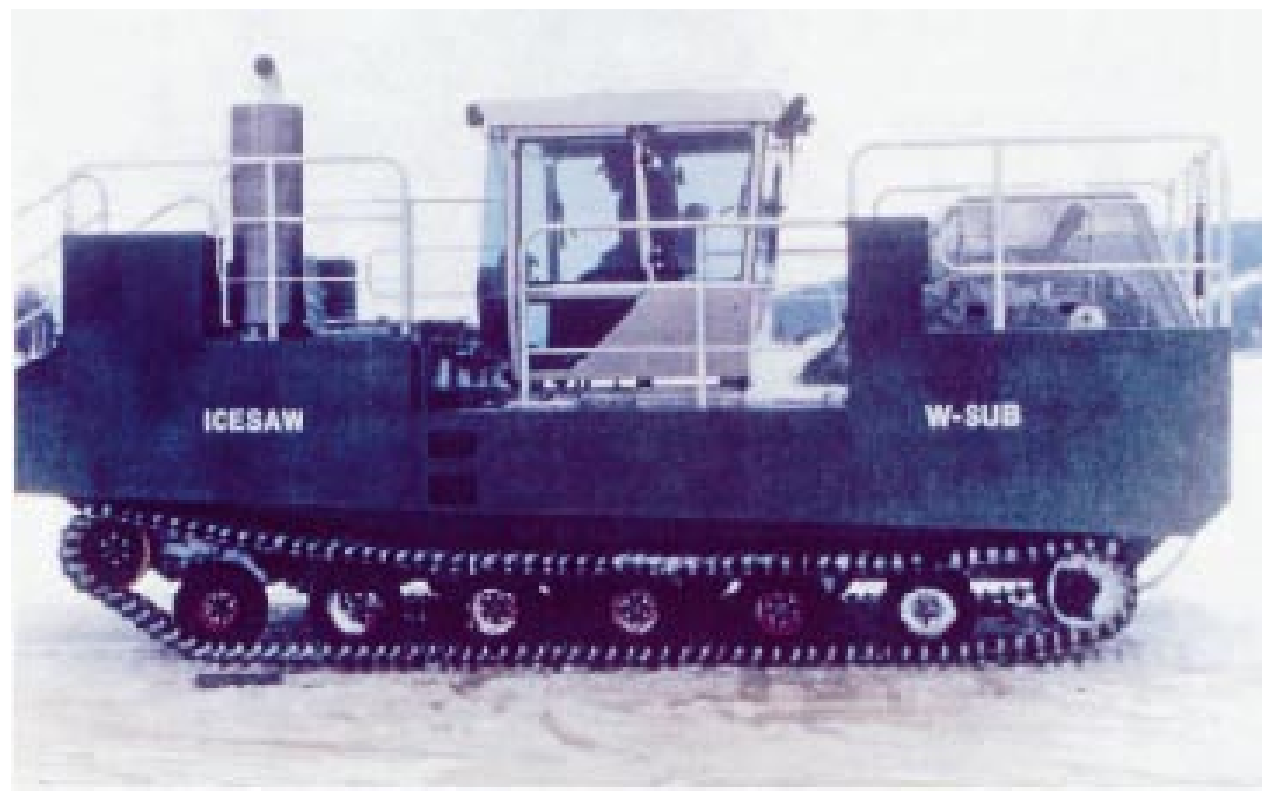

Figure 3. ICESAW used for cutting river ice (photo courtesy of Mobimar, Ltd.).

It has a retractable circular saw that will cut through ice as thick as $1.2 \mathrm{~m}$ in a single pass at speeds of $0.5-1 \mathrm{~km} / \mathrm{hr}$. There is only one of these in existence, and it has been used extensively in Finland since the early 1990s to relieve ice jam flooding on both rivers and lakes. It is capable of cutting a $300-\mathrm{m}$-wide $\times 10-\mathrm{km}$-long section of ice at a lake inlet in about 8 hours. In the spring of 1996 it was used to cut over 146 lineal km of trenches on nine rivers in Finland.*

The Finnish built Watermaster ${ }^{\mathrm{TM}}$ and Canadian built Amphibex ${ }^{\mathrm{TM}}$ are similarly designed amphibious excavators that have been used for ice control. They have an ice cutter attachment, a circular saw that bolts to the back, that will cut up to $0.5 \mathrm{~m}$ thick ice at a rate $0.37 \mathrm{~km} / \mathrm{hr}$. These amphibious excavators have also be used to break ice (see Fig. 12) and have been used extensively in Canada on rivers around the St. Lawrence Seaway.

The Aquaglace ice trencher was used to cut ice on the Beaurivage River in 1986 (Belore et al. 1990). This is essentially a conventional walk-behind soil trencher fitted with flotation pontoons to prevent its loss when operating on thinner ice.

\section{Channeling plow}

Tsykin (1970,1982) describes an ice channeling plow, used in the former Soviet Union, to cut tri-

*Personal communication, E. Mykkanen, Finnish Environment Agency, Kokkola, Finland, 5 September 1997. angular furrows in an sheet ice. The plow is mounted on a sledge (Fig. 4a) and drawn by a tractor. The broken ice is cleared from the channel with a small clearing wedge (not shown). Typically the mode of operation with the plow is to cut a channel about two-thirds the depth of the ice cover. This channel then fills with water, and quite often a skim covering of ice forms on the water surface. The skim ice stops evaporative cooling of the water, yet still allows solar energy to warm the water. The addition of solar energy causes convection cells to be set up in the channel (Fig. 4b), which melt the remaining ice at the bottom of the channel. The ice at the bottom of the channel melts out even if there is no skim ice covering the water, but at a slower rate.

The tractive or drawbar force, $P$, required to pull the plow through the ice as a function of cutting depth, $H$, was determined empirically by Tsykin and is

$$
P(\mathrm{~kg})=984-105.7 H+7.08 H^{2}-0.071 H^{3}
$$

where $H$ is in $\mathrm{cm}$. The plow requires about $47 \mathrm{kN}$ of tractive force to be drawn at its maximum cutting depth of $0.6 \mathrm{~m}$. A 180-kW Soviet GT-90 amphibious tractor, weighing about $9,000 \mathrm{~kg}$, was used to cut channels to a depth of $0.35 \mathrm{~m}$ at a rate of $12-15 \mathrm{~km} / \mathrm{hr}$ (Tsykin 1982). Conventional tractors rated at $150-190 \mathrm{~kW}$ can weigh as much as 


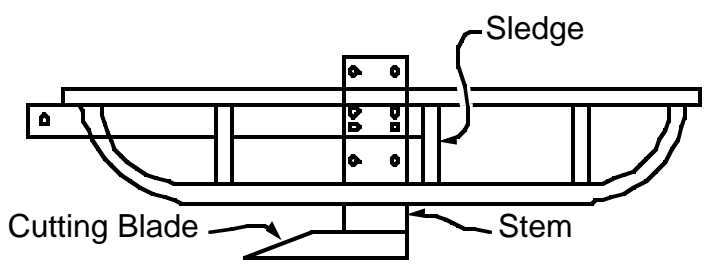

a. Schematic of the plow.

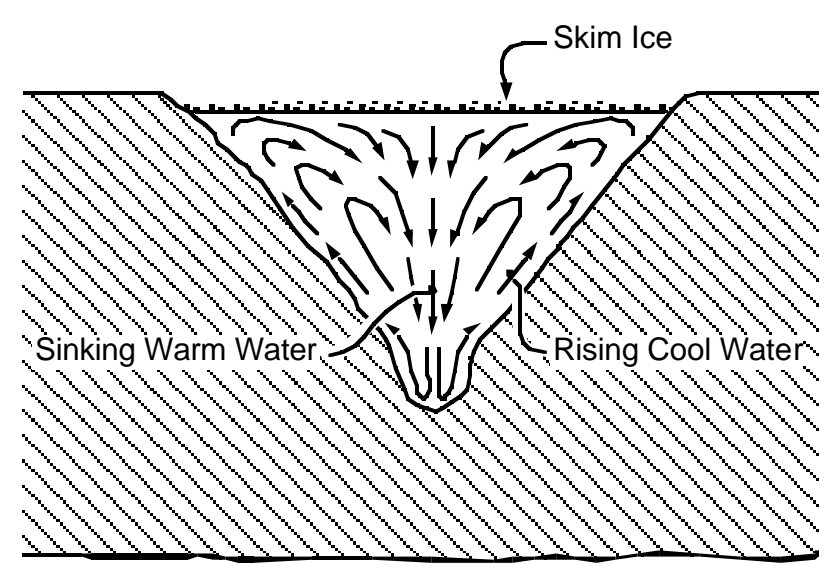

b. Cross section of furrow made using the channeling plow.

Figure 4. Ice channeling plow developed by Tyskin (1970).

$20,000-26,000 \mathrm{~kg}$, which would require an ice thickness of at least 0.6 to $0.7 \mathrm{~m}$ to carry such vehicles. On rivers, where the ice thickness can be highly variable, it would not be advisable to put such heavy equipment on the ice, even if the nominal ice thickness were sufficient to carry the weight. However, in areas where the ice is of uniform thickness, such as lakes and backwater regions, it may be safe to deploy such equipment, provided the ice thickness is sufficient and the operation is carried out early in the spring when average air temperatures are still well below freezing. As an alternative to putting heavy equipment on the ice, the plow could also be drawn by a truck-mounted winch located on the river bank. Tsykin (1982) also describes using shipboard winches and towboats to draw the channeling plow through the ice to weaken the ice cover in advance of icebreakers.

\section{Water jet and thermal cutting}

Though water jet and thermal cutting has not been used extensively to cut ice, included is a brief discussion of the technology as it applies to floating ice. Water jet cutting is accomplished by pressurizing water to $100 \mathrm{MPa}$ or more and discharging it through a small nozzle. This supersonic water stream can be used to cut rubber, cloth, and food products. With the addition of an aggregate to the water, the jet can be used to cut common metals such as aluminum and steel. Calkins and Mellor (1976) describe the use of a water jet, without aggregate, to cut both dry and floating ice ("dry ice" in this instance is referring to ice that is not in or floating on water). They were able to cut 0.9 -m-thick dry ice at a rate of $2.3 \mathrm{~m} / \mathrm{min}(0.01$ $\mathrm{m}^{3} / \mathrm{min}$ ). The ice removal rate for floating ice was about the same or better as that for dry ice (0.01$\left.0.03 \mathrm{~m}^{3} / \mathrm{min}\right)$, yet the jet could not cut much deeper than $15-17 \mathrm{~cm}$, since the water quickly disperses the energy of the jet, making full penetration of thick ice on a single pass impossible. Another drawback of using a water jet to cut ice is that it has a kerf width of only $0.5-1 \mathrm{~cm}$, which quickly freezes back.

Bojun and Si (1990) developed a specially designed steam jet (designated BRQ10-2) for cutting sheet ice in front of dam piers and gates. The BRQ10-2 produces dry saturated steam, which is delivered at 0.5 to $0.6 \mathrm{MPa}$ through a handheld wand. The wand is fitted with either a single nozzle, or a manifold with as many as 34 nozzles. This design is capable of cutting a $15-$ to $20-\mathrm{cm}-$ 
wide slot in the ice with an ice removal rate of about $0.002-0.003 \mathrm{~m}^{3} / \mathrm{min}$. It is interesting to note that the specific energy (amount of energy required to remove a unit ice volume) of this operation is about $34 \mathrm{MJ} / \mathrm{m}^{3}$. By comparison, simple melting of the ice requires about $300 \mathrm{MJ} / \mathrm{m}^{3}$. This ninefold increase in cutting efficiency of the BRQ10-2 suggests that the steam jet is not melting the ice, but is eroding the ice from the jet velocity.

\section{Hole cutting}

Holes cut in the ice cover can be used to reduce the integrity of the cover and curtail ice jam formation. Holes can be created by a variety of methods such as ice augers, posthole diggers, thermal drilling equipment, and explosives. Typically the holes are cut about 1 month prior to the ice-out date. Holes on the order of $20 \mathrm{~cm}$ or more in diameter appear to be sufficient to prevent freezeback during early spring.

Hole drilling operations have been carried out since 1989 to alleviate ice jamming and flooding at the confluence of the Oconto River and the Green Bay in the city of Oconto, Wisconsin (Fig. 5). In 1989 holes were cut around bridge piers, islands, and river bends (indicated by the dashed lines in Fig. 5) to create shear lines for the ice to fail along (DenHartog and Gooch 1989). Although this severely weakened the ice along these lines, an ice jam still formed at Ajax Island that had to be removed using blasting (Bonetti 1989). In 1991 a combination of trenching and hole drilling was used to weaken the ice, with the result being that no ice jam occurred that spring. In 1992 the city of Oconto started weakening ice by drilling $22-\mathrm{cm}-$ diam. holes in the ice cover from the railroad bridge to the bay, a distance of about $5 \mathrm{~km}$ (see Fig. 5). A posthole digger mounted on the back of a lawn and garden tractor (Fig. 6a) was used to drill the middle third of the river. Holes were spaced about 2.4-3 m apart (Fig. 7). Although the unmodified posthole digger was a great improvement over hand-held ice augers, the cutting speed of the auger was improved significantly by replacing the stock auger tip with a spade tip (Fig. 6b), which allowed cutting 150 to 200 holes per hour in the 35- to 40-cm-thick ice cover. The entire operation takes about 2 weeks and costs about $\$ 2,000$ annually. Since 1991, when the city of Oconto began employing this method, ice jams have not formed on that stretch of the river.

Moor and Watson (1971) used small explosive charges to create a line of holes in the ice cover along which the ice would fail. In this case two sticks of ditching powder were packed in $3.8-\mathrm{cm}-$ diam. holes. The resulting holes were $1.7 \mathrm{~m}$ in diameter. Smaller holes could be cut using shape charges (Mellor 1986). Hot water drills have been used for cutting holes ranging from $0.1-1 \mathrm{~m}$ in diameter and can penetrate ice as thick as $2 \mathrm{~m}$ or more (Francois 1984, Echert and Kollé 1986).

The holes appear to not only mechanically weaken the ice cover, but can also cause localized melting of the ice cover in the vicinity of the hole. This is shown schematically in Figure 8. The initial drilled hole has straight sides, as indicated by

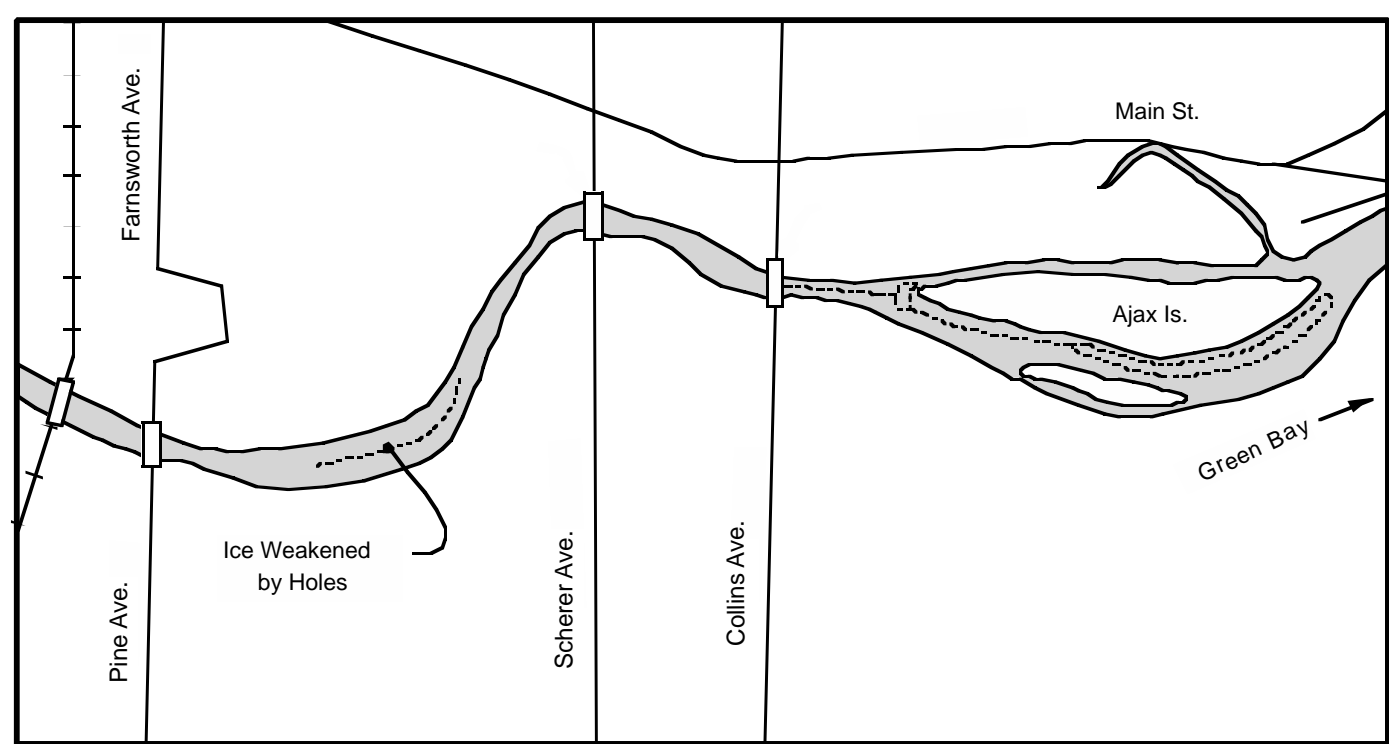

Figure 5. Hole drilling operations on the Oconto River at Oconto, Wisconsin. 


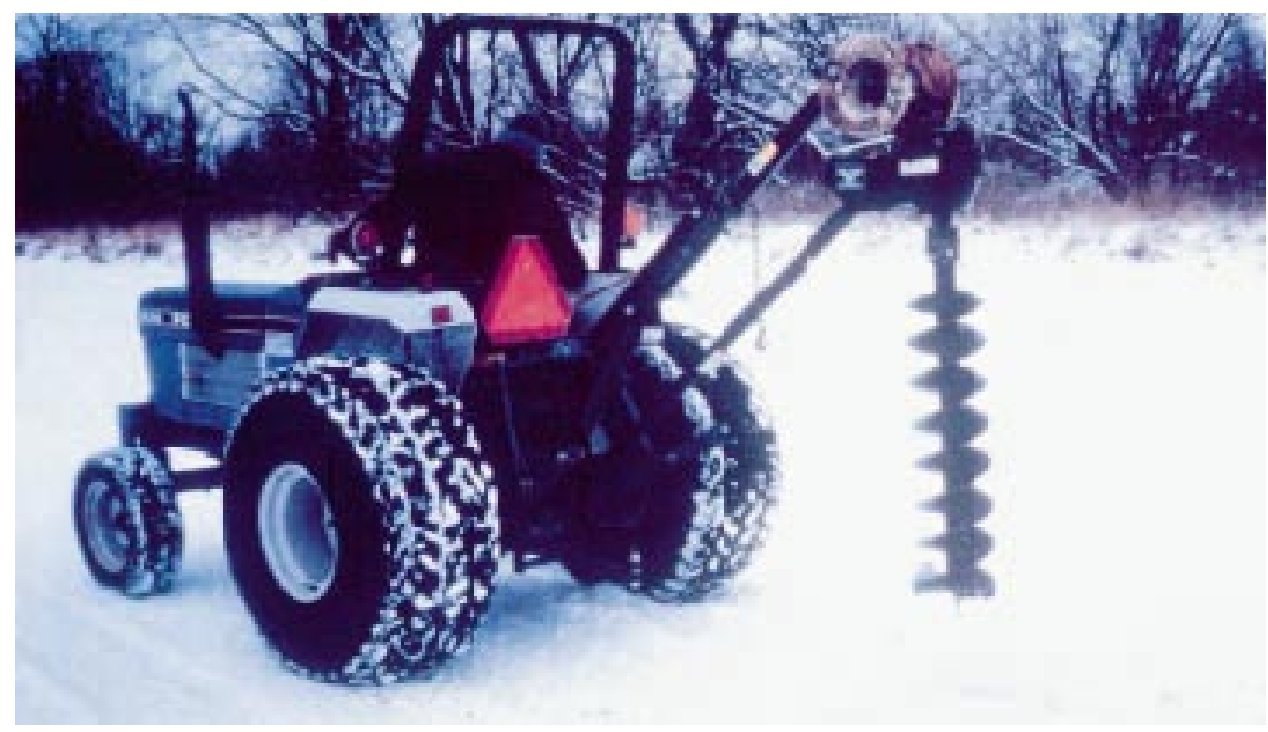

a. Posthole digger mounted on the back of a tractor.

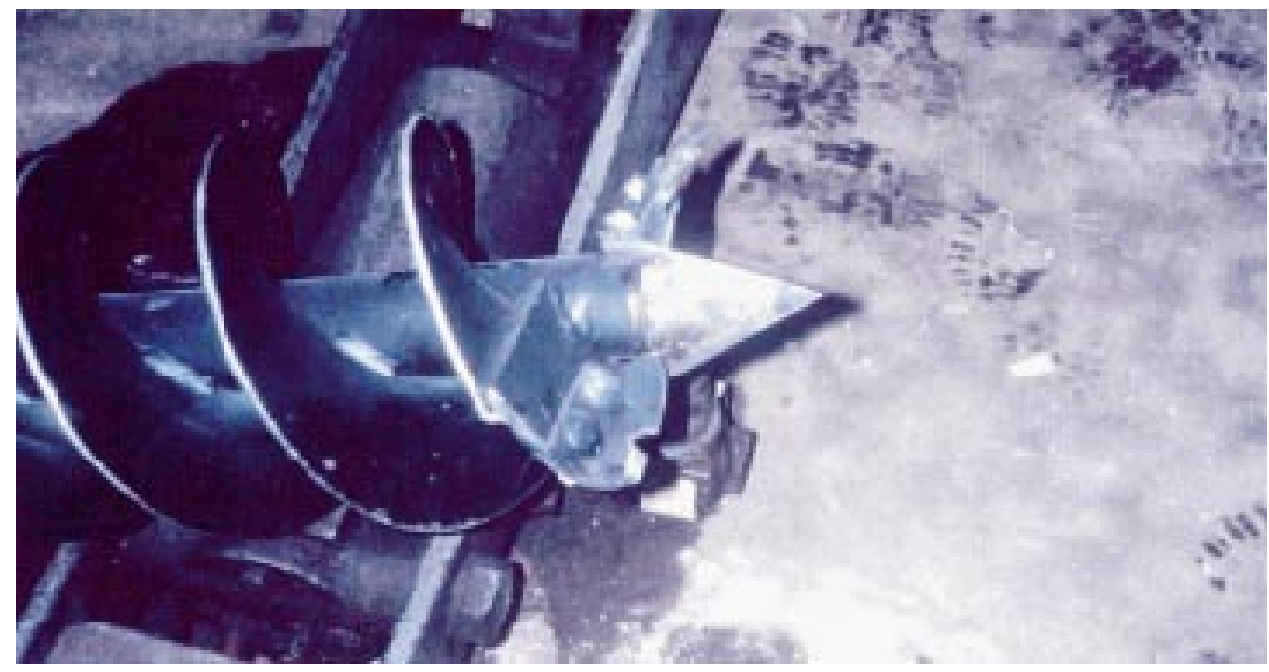

b. Close-up of auger showing the modified auger tip.

Figure 6. Equipment used for drilling holes in the Oconto River.

profile 1 in Figure 8. Over time, the ice below the water line melts back away from the hole, as indicated by profiles 2 and 3 . Thus the influence of the holes on weakening the ice cover increases with time, underscoring the advantage realized by cutting the holes several weeks before river breakup. This illustrates an important point with regard to nonstructural measures. Often there is more than one governing physical process that makes a nonstructural measure successful. In this case, drilling the holes in the ice mechanically weakens the ice cover. Yet further weakening takes place through thermal processes such as enhanced wa- ter-ice heat transfer due to the presence of the holes, and warming of the water by direct exposure to sunlight through the holes. This additional thermal degradation may be crucial to the success of the hole drilling operation; thus the interplay of the various physical processes at work must be considered as part of the overall ice weakening strategy.

\section{Icebreaking}

Icebreaking on rivers and harbor areas has been used extensively in Belgium, Canada, Finland, France, Germany, the Netherlands, the former 


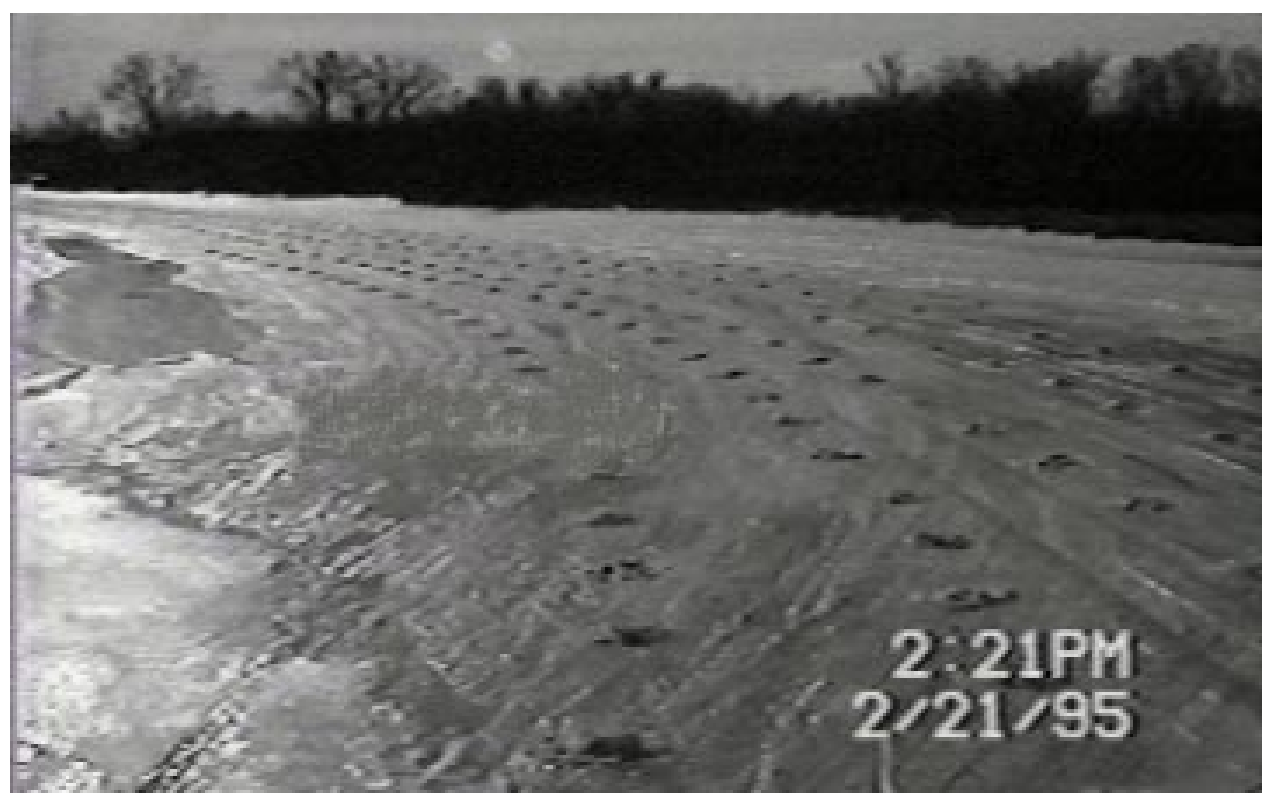

Figure 7. Holes drilled in the Oconto River ice cover at the upstream end of Ajax Island.

U.S.S.R., and the United States. Icebreaking may be done as an advance measure to prevent ice jams (discussed in this section) as well as a countermeasure to break up existing jams. This section will focus on the use of icebreaking as an advanced measure only. One icebreaking technique consists of breaking an entire ice cover early in the spring and leaving the broken ice in the channel. This remaining brash ice cover then is flushed out by the spring freshet, thereby preventing an ice jam. In some locations simply breaking the ice cover is not sufficient, so icebreaking is often accompanied by clearing the ice out of the problem reach as well. Ice clearing can be accomplished by breaking the ice cover, starting at a downstream open water area and progressing upstream into the solid cover, relying on the river flow to carry the ice away. If the pre-freshet flow is not sufficient to clear the ice, it may need to be cleared after it is broken by use of icebreaking ships, towboats, or excavation equipment. In any case, careful consideration of the effects of the loose, broken ice on downstream reaches must be addressed to avoid putting downstream communities at increased risk due to the

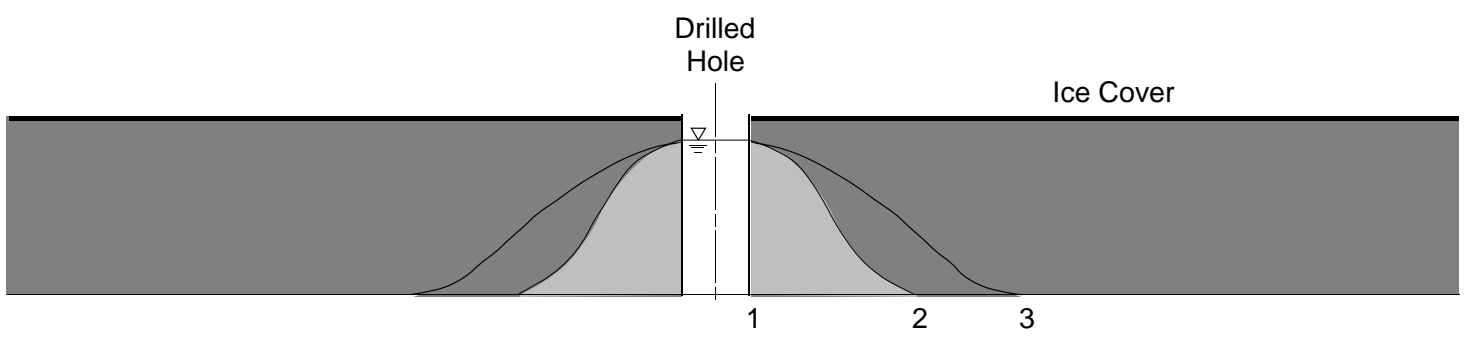

Water

River Bed

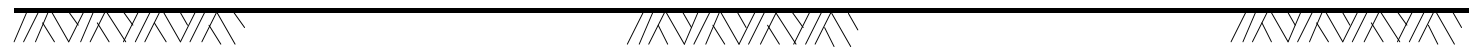

Figure 8. Typical observed ice profile around a hole drilled in ice with water flowing by it. The original hole is shown in profile 1. Profiles 2 and 3 show the progressive melting of the ice away from the hole (after Haehnel 1996). 
icebreaking operation. This may require establishing a storage location for the broken ice (i.e., pushing the ice into a downstream reservoir) or releasing the ice floes in low concentrations to ensure the ice does not jam before it reaches open waters.

Icebreaking to mitigate breakup ice jams is done annually on the Rideau River in Ottawa, Ontario, Canada. The Rideau is a shallow, 45-m-wide river. In Ottawa the ice has been broken annually since 1897 to prevent ice jam flooding in the city.* Twelve kilometers of ice is broken starting near the confluence of the Rideau and Ottawa Rivers and progressing up the Rideau. The ice is flushed into the Ottawa River by regulating the flow out of the Long Island dam located about $17 \mathrm{~km}$ upstream of Ottawa on the Rideau River (Deugo 1973). The breaking and flushing operation is timed so that the river reach is clear of ice about 2 weeks prior to the spring freshet. Historically, the ice has been broken using explosives. However, in more recent years the bulk of the ice is broken using the an amphibious excavator.* Nevertheless, blasting is still used on sections of the river that are inaccessible to the excavator, such as under low bridges, or on ice that is too thick for the excavator to break. In places where blasting is prohibited (e.g., near sewer lines, water mains, and bridges) slots are cut in the ice that are parallel to the shore. These slots are cut about $15 \mathrm{~m}$ from the shore and extend about $30 \mathrm{~m}$ upstream and downstream of the utility. Three lineal kilometers of slots need to be cut to ensure the safety of utilities and bridges. Once the slots are completed, the icebreaking and flushing operation commences.

The icebreaking is carried out in concert with reservoir releases, and proceeds upstream from the confluence. First the reservoir is ponded at the Long Island dam to collect additional water for the flushing operation. The ponded water is then released, bringing the flow in the Rideau up to 35 $\mathrm{m}^{3} / \mathrm{s}$, and icebreaking commences (Deugo 1973). When the flow drops below $35 \mathrm{~m}^{3} / \mathrm{s}$, icebreaking is halted until the reservoir is again filled and a flow of $35 \mathrm{~m}^{3} / \mathrm{s}$ can be reestablished. Experience has shown that it is not necessary to remove the entire ice cover, but rather to concentrate on removing the ice over the main channel. The remaining shore-fast ice that extends 6 to $15 \mathrm{~m}$ into the channel usually just melts in place and does not cause a problem.

\footnotetext{
*Personal communication, W.M. Miner, City of Ottawa,
} Ottawa, Ontario, Canada. 1997.
Icebreaking has been accomplished using a variety of methods ranging from conventional icebreaking ships to the use of excavation equipment and blasting. Below is describe the various methods that have been used to break ice.

\section{Icebreaking vessels}

Icebreaking vessels are limited to rivers that have sufficient draft for their passage. Also river icebreaking vessels must have large power plants that not only allow overcoming ice-hull friction but also can produce large forward speeds (as much as 10 knots) above the downstream water current (Bolsenga 1968). Underpowered icebreakers in swift flowing streams will not have enough speed, relative to the ice cover, to break the ice. Furthermore, intake designs for the engine cooling requires special consideration to avoid blockage by the broken brash ice (Bolsenga 1968, Michel 1971).

For breaking river ice, three types of vessels are typically used:

- Conventional icebreakers that break the ice in flexure by riding up on the ice cover.

- Ordinary towboats and towboats with reinforced frames and ice linings.

- Towboats or tugs that are fitted with icebreaking "plows" or prows designed for efficient icebreaking.

Below is a summary of the important design features and operation of each of these vessels.

Conventional icebreakers. Icebreakers are ships that have been designed specifically for traveling in ice-laden waters. This requires a hull that is stronger than conventional ships and constructed out of low temperature steel. The hull is shaped to facilitate the breaking of ice. Conventional hulls are designed to break the ice by riding the bow of the ship onto the ice, after which the ice breaks in flexure under the weight of the bow. Furthermore, to overcome the additional ice resistance the propulsive power plants must be larger than what is used in conventional ships. Additional systems are also employed to improve the performance of the icebreaker such as

- Low friction hull coatings and cladding

- Hull air lubrication systems

- Hull heating at the waterline

- Pitching systems that induce a rocking motion of the ship about the long axis of the hull 


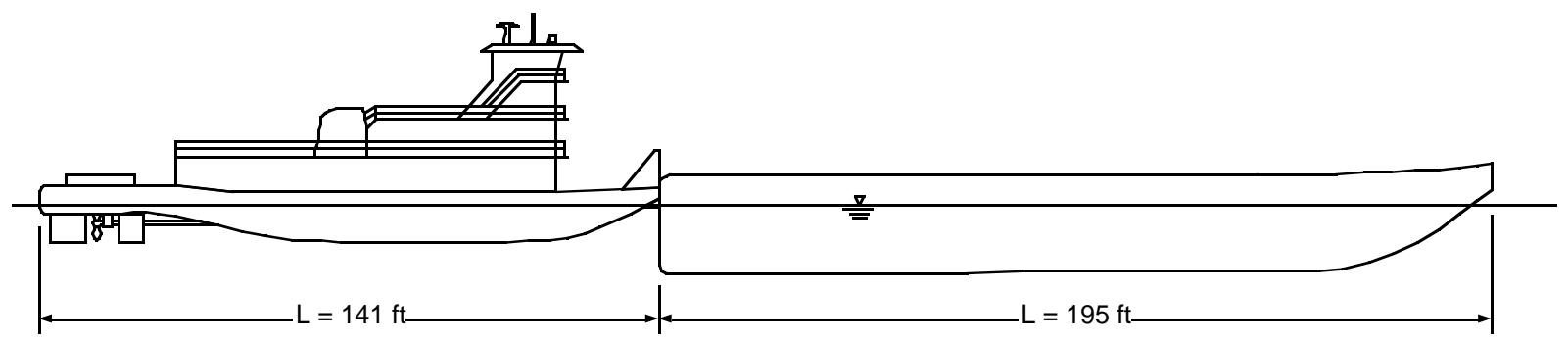

Figure 9. Tow with a raked barge used for breaking river ice.

- Water spray systems

- Nonconventional hull forms to optimize icebreaking and clearing of channel.

Detailed discussion of these systems are beyond the scope of this report. A full treatment of icebreaker design is given in Sodhi (1995).

River towboats. Towboats are the mainstay of ice control on U.S. inland waterways, principally because they are on site when problems arise and they are very powerful (typically $2700-4600 \mathrm{~kW}$ ).
Ordinary towboats are limited to breaking ice thicknesses of 15 to $25 \mathrm{~cm}$ without damaging the hull (Bolsenga 1968). Thicker ice may be broken using explosives and then cleared using towboats. To extend the use of towboats in heavy ice, often 1.5-cm-thick steel cladding is installed at the ice belt to reinforce the hull (Ashton et al. 1973).

Ice prows. The use of icebreaking prows in front of conventional ships for breaking ice on rivers and canals was first done by the Dutch in the 1890s

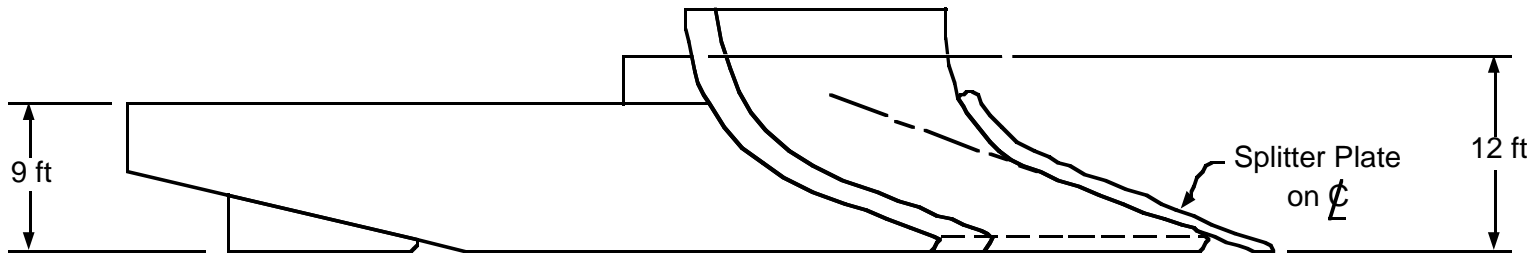

Elevation

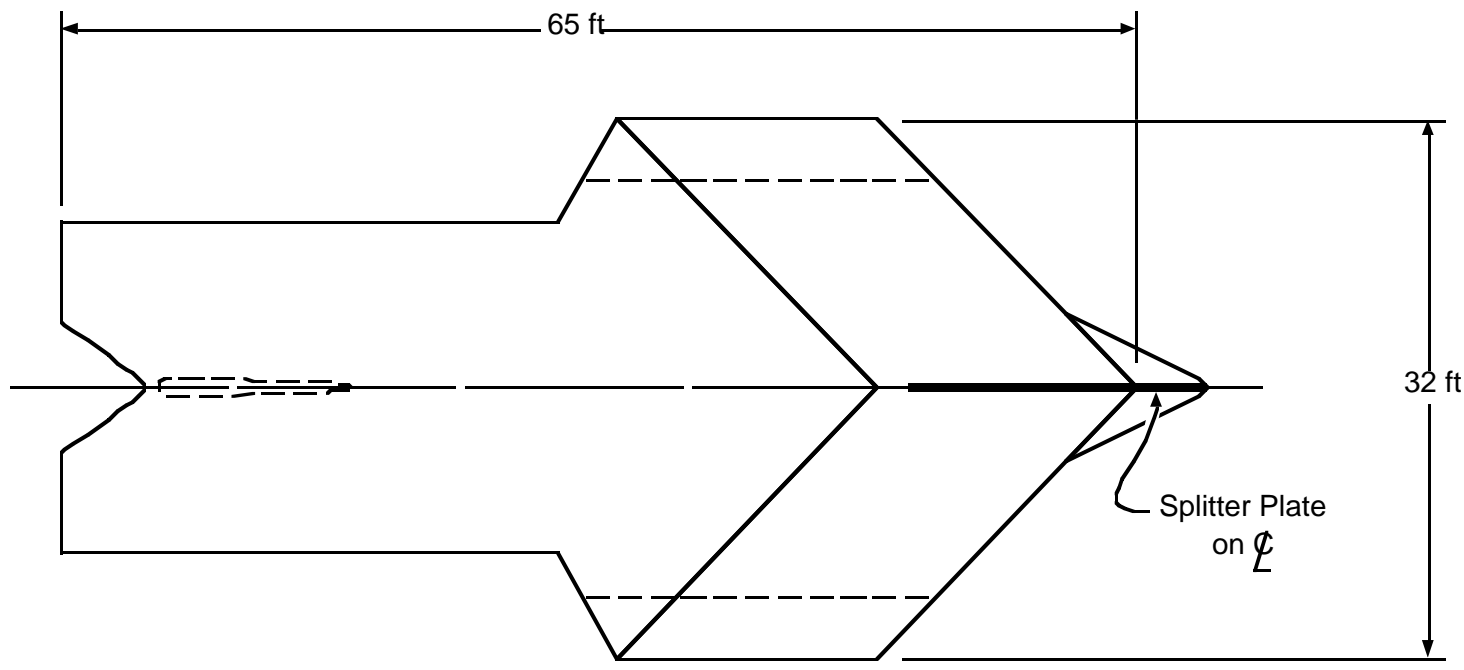

Plan View

Figure 10. Alexbow ice prow. 
(Sodhi 1995). Ice prows have been used routinely since the early 1940s to break ice in Europe and the United States (Bolsenga 1968). In its simplest form, an ice prow can be a raked barge coupled to the front of a towboat (Fig. 9). Typical prows are barges with the bow shaped to provide efficient icebreaking. The hull is also reinforced to withstand the ice forces.

Icebreaking prows used in the former U.S.S.R. have knife edges at the front of the prow, and the hull shape pushes the ice to the side and under the adjacent ice cover (Tatinclaux and Martinson 1988). These are effective at creating a clear, smoothed edge channel, and can be used in both sheet and hummocked ice with reduced icebreaking power requirements.

The Alexbow (Fig. 10), designed by Scott Alexander in the 1960s, breaks the ice in uplift and deposits the ice on the adjacent ice cover. In field trials the bow form, pushed by a $1000-\mathrm{kW}$ tow, successfully broke ice up to $0.5 \mathrm{~m}$ thick at a speed of 2-3.5 knots (Alexbow Ltd. 1967). However, field trials of the bow form conducted by the U.S. Coast Guard showed that it required considerably more power to break ice than conventional bow forms; trials in Canada, Europe, and the former U.S.S.R. confirmed these findings (Ashton 1986).

Air cushion vehicles (ACV) can also be pushed in front of a towboat to improve icebreaking capability. The ACV pushes the supporting water out from under the ice, allowing the ice to break under its own weight (Hinchley et al. 1991). The use of ACVs is effective at reducing the icebreaking forces when traveling through sheet ice but cannot be used in brash ice.

Icebreaking operations. In a typical icebreaking operation, two or more icebreaking vessels may work together in echelon, breaking ice starting at the downstream edge of the ice cover and advancing upstream into the unbroken cover. The ice is broken into pieces that are less then a quarter of the river width. Given sufficient water velocity, the broken ice pieces are carried downstream by the water current. Often additional vessels will need to be used to clear the broken ice and move it downstream, as well as monitoring drifting ice pieces to ensure that they do not jam in downstream reaches. When the broken ice begins to arch across the river, these vessels are used to break up the arch and maintain clear passage of the ice to open waters. When the ice begins to run, icebreakers may also be deployed to assure the safe passage of the drifting ice (Bolsenga 1968).
The thickness of ice that can be broken by an icebreaker can be extended by cutting or weakening the ice in advance of the icebreaker. Tsykin (1982) describes making a single furrow in the ice in front of the stem of the advancing icebreaker using the channeling plow. Tsykin reports this operation allowed the icebreaker to break a channel at 2-2.5 times faster or break ice up to twice its design thickness. Also, the U.S. Coast Guard tested a hull design that had three ice cutters, one at the stem and one on each side of the beam that cut the ice in front of the icebreaker. This design was shown to cut the power requirements for breaking level ice by $30 \%$ (Lewis et al. 1973).

\section{Air cushion vehicles}

Air cushion vehicles (ACVs) are routinely used to break up river ice on tributaries to the St. Lawrence Waterway and on Lac St. Pierre. The ice can be broken by two mechanisms. Traveling at low speeds, the air cushion pressure depresses the water in the vicinity of the vehicle leaving the ice unsupported. The ice then fails under its own weight, and the broken swath is roughly equal to the beam of the craft. The maximum thickness of ice that can be broken in this way is approximately $90 \%$ of the air cushion pressure, expressed as head of water (U.S. Army 1982). At higher speeds the ACV sets up a standing wave about half the craft length astern in the ice cover, which moves with the speed of the craft, and breaks the ice at the crest of the wave. The resulting broken channel is considerably wider than the beam of the craft. The Voyageur - a 45-tonne, 20-m-long Canadian Coast Guard ACV with an air cushion pressure of $26 \mathrm{~cm}$ of water-traveling at a speed of $25 \mathrm{~km} / \mathrm{hr}$ is able to break sheet ice up to a meter thick on the tributaries to the St. Lawrence River. However, at low speeds the Voyageur is capable of breaking ice only $23 \mathrm{~cm}$ thick (Robertson 1975). ACVs are limited to breaking smooth sheet ice, because uneven ice surfaces damage the side skirts.

Robertson (1975) conducted field tests using the Voyageur to break ice and reported this ACV was able to break over $250 \mathrm{ha} / \mathrm{hr}$ in 30 - to $50-\mathrm{cm}$ ice in open areas. In restrictive areas such as in harbors and around slips, the icebreaking rate was reduced to about $11 \mathrm{ha} / \mathrm{hr}$. The size of the resulting ice pieces were about $3 \mathrm{~m}$ square.

Though an ACV can open a track in an unbroken ice cover, clearing of the ice must be accomplished by following vessels or water current (Tatinclaux and Martinson 1988). In long, narrow tracks running into the sheet, the ice can easily arch 
across the width, and water current alone cannot reliably clear the ice. Therefore, when ice clearing is dependent on water current alone, a more effective icebreaking strategy is to break the ice across the downstream edge of the cover by moving the ACV over the edge of the cover in circular motions, breaking off ice pieces that can then be carried away by the river current (Robertson 1975, Michel 1984).

\section{Construction equipment}

Icebreaking has also been accomplished using various types of construction equipment including bulldozers, excavators, dragline buckets, and cranes with wrecking balls. The bulldozers are useful only in shallow rivers and can cause considerable damage to the bed and associated habitat. On narrow rivers excavators working from the shore and bridges can break ice without having to work in the river. Bucket dredges (Fig. 11) and cranes have considerably longer reach and, working from the bank, can be used to clear ice on rivers that are 50 to $100 \mathrm{~m}$ wide. All of these methods require easy access to river along much of the length where the ice is to be broken.

\section{Blasting}

Use of blasting to clear ice dates back over 200 years, with the first successful attempt being noted in Germany in 1758 (Van der Kley 1965). There are two types of explosive devices that have been used to break up ice, chemical explosives and compressed gas cartridges. As it turns out, there is very little difference in the performance of these two methods. Since chemical explosives are the most widely used, their performance will be discussed first. Following this, the differences between chemical and compressed gas explosives in terms of implementation and performance will be identified.

Chemical charges. Extensive experimental work studying the ability of explosive chemical charges to break up level ice were carried out by Van der Kley (1965), Kurtz et al. 1966, Wade (1966), Frankenstein and Smith (1966) and others. Mellor (1986) compiled the available field data and developed basic guidance on use of explosives to break up a level ice cover. Those results are summarized here. For a given charge size the maximum crater diameter is realized with the charge placed just under the ice cover. The optimum charge size, $W_{\text {opt }}$, for a given ice cover thickness, $t$, is given by

$$
W_{\text {opt }}=21 t^{3}
$$

where $t$ is the ice thickness in meters, and $W_{\text {opt }}$ is in kilograms. For English units the charge size is

$$
W_{\text {opt }}=1.4 t^{3}
$$

with $t$ in inches and $W_{\text {opt }}$ in pounds. The resulting crater diameter, $D$, is

$$
D=15 t
$$

Since there is little radial cracking that occurs beyond the crater, the effective damage is no greater than 15t. Thus, for complete destruction of an ice cover hole spacing should be about $15 t$. For weakening of an ice cover, spacing can be greater then 15t. Simultaneous detonation (or

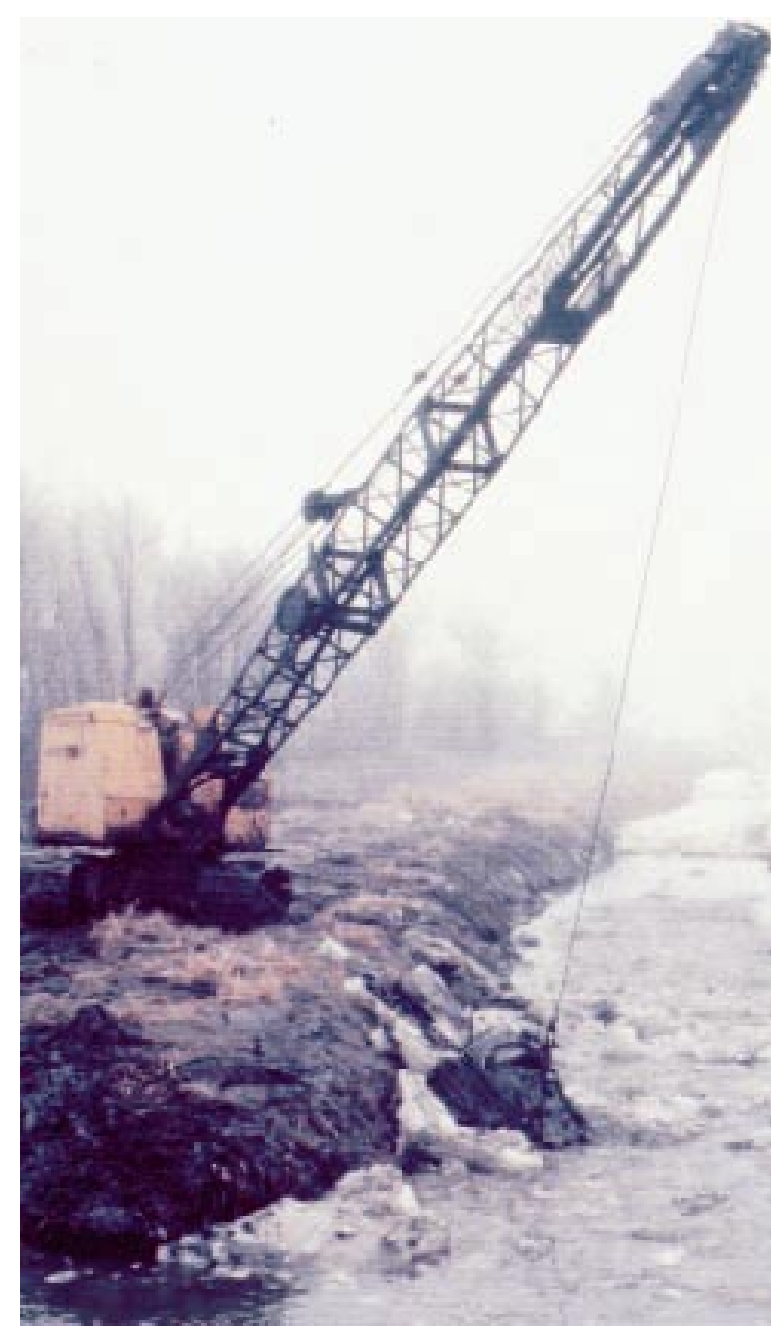

Figure 11. Using a bucket dredge to break ice in a river. 
nearly so) provides the best results for breaking up large sections of a river. Work should proceed from the downstream edge of the ice cover, allowing the river flow to carry away ice broken by the blast. The majority of the ice is broken up into small pieces less than $10 \mathrm{~cm}$ across; however, it is not uncommon for pieces as large as $0.9 \mathrm{~m}$ in diameter to be hurled 18 or more meters from the blast site (Moor and Watson 1971).

These results are largely independent of explosive type "since the specific energy of typical explosive types varies within fairly narrow limits" (Mellor 1986). Furthermore, it appears that ice properties have little effect on the extent of damage as well. The various types of chemical explosives that have been used include ammonite, ammonium nitrate-fuel oil (ANFO), black powder, dynamite, C-4, C-3, TNT, thermite, and tetrytol (Bolsenga 1968). Of these ANFO and C-4 seem to be the most popular. The advantage of ANFO is that the components, by themselves, are not explosive, which simplifies storage and transportation of the materials.

Placement of charges can be accomplished by drilling holes in the ice, then dropping the charge through the ice and suspending it by a rope tied to a wooden crosspiece that bridges across the hole. The hole can also be made using shape charges placed on the surface. For some types of explosives, weight may need to be added (e.g., bricks) to keep the charge under the ice cover. Proper safety procedures should be followed when handling explosives and carrying out the operation. These include obtaining proper permitting (including environmental), notification of the Federal Aviation Administration to assure aircraft are kept away from the blast area, and coordination with local law enforcement to ensure sightseers stay a safe distance away from the blast zone and overseeing evacuation of local residents if necessary (White and Kay 1997).

Compressed gas. Compressed gas cartridges (either carbon dioxide or air) are used by the mining industry as an alternative to chemical explosives. The carbon dioxide cartridges contain liquid carbon dioxide compressed to $13.8 \mathrm{MPa}$ in a shell that has a sealing disk that ruptures at pressures in the range of 70 to $130 \mathrm{MPa}$. An electrically actuated chemical heater is submerged in the liquid $\mathrm{CO}_{2}$. When the heater is fired, the pressure increases rapidly, the seal disk ruptures, and the $\mathrm{CO}_{2}$ is released through the blast ports. The air cartridges contain a storage chamber filled with air com- pressed to $83 \mathrm{MPa}$. On one end of the chamber is a pneumatically actuated valve which, when opened, allows rapid discharge of the compressed air.

Tests using compressed gas to break ice were conducted by Mellor and Kovacs (1972) on lake ice. They found that the these systems (containing about $2 \mathrm{~kg}$ of compressed gas released at 70 to $80 \mathrm{MPa}$ ) were equivalent to $0.5 \mathrm{~kg}$ of dynamite and were capable of breaking ice up to $0.5 \mathrm{~m}$ thick, producing a crater diameter of $4 \mathrm{~m}$ or more. Some advantages are noted by Mellor and Kovacs for use of this system over chemical explosives:

- The ice is largely broken in flexure, yielding larger ice fragments, and significantly reduced "flyrock."

- Peak pressures even a few centimeters away from the shell are insufficient to damage hydraulic structures, ship hulls, etc.

Nevertheless, similar safety precautions used for chemical explosives should be used for compressed gas blasting as well. Also, consideration for recovery of the reusable cartridges must be addressed.

Under-ice combustion. Ice can also be fractured in upward bending by the gas bubble created from combustion under ice. Mellor (1980) describes experiments using a combustion chamber filled with propane and air compressed to $410-650 \mathrm{kPa}$ and ignited with a spark plug. This system was effective at breaking up to $30 \mathrm{~cm}$ of ice.

\section{Other icebreaking methods}

Archimedean screw tractor. Archimedean-screw tractors are amphibious tractors that use twin contrarotating Archimedean screws for propulsion. The screws are wound around large tanks that also serve as pontoons and provide the flotation for the tractor. Edworthy et al. (1982) describes using of an 11-tonne Japanese built AST-002 tractor for ice management. Icebreaking was accomplished in two modes. Up to $45 \mathrm{~cm}$ of the ice was broken by the tractor climbing onto the edge of the ice, causing the ice to fail in flexure, and breaking off ice pieces 0.75 to $3 \mathrm{~m}$ on a side. Ice up to $80 \mathrm{~cm}$ could be broken by "fatiguing" the ice, by repeatedly driving onto the edge and backing off or by rocking on the ice edge by quick forward and reverse motions. The AST-002 could break level ice up to $45 \mathrm{~cm}$ thick ice at a rate of 3-4 ha/ hr, while in ice 45 to $60 \mathrm{~cm}$ thick the rate was reduced to $0.6-0.75 \mathrm{ha} / \mathrm{hr}$. In brash ice 


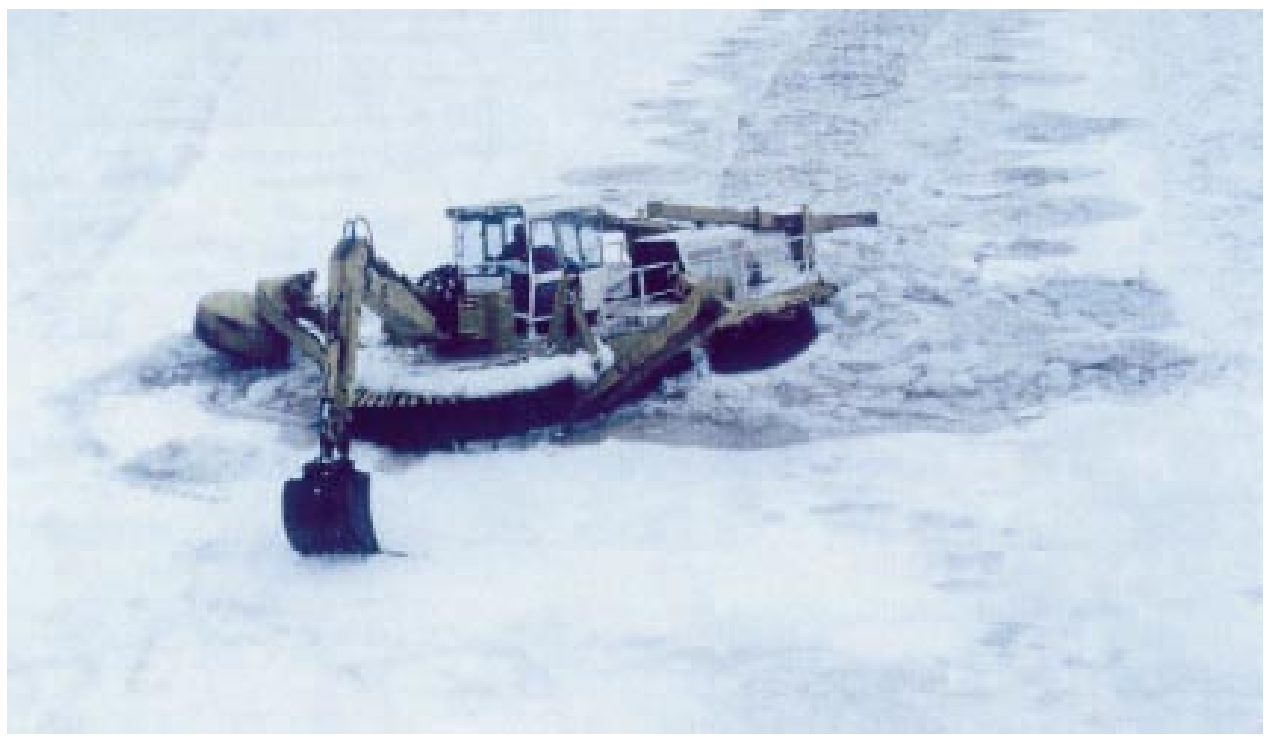

Figure 12. Breaking ice with an amphibious excavator on the Aroostook River, Ft. Fairfield, Maine.

(e.g., refrozen ship tracks) the AST-002 broke ice at a rate of about $4.2 \mathrm{ha} / \mathrm{hr}$.

Amphibious excavators. Amphibious excavators, such as the Finnish-built Watermaster or Canadian built Amphibex (Fig. 12) can be used over large stretches of river for which there is poor access from the shore (provided there are not low bridges that limit travel by river). They offer an advantage over conventional icebreakers because they can operate in narrow, shallow rivers. These have been used extensively since 1989 to break ice in Canada (e.g., the Rideau and DuLoup Rivers) and since 1995 in northern United States. The ice is broken by using the backhoe to pull the 22-tonne excavator unto the unbroken ice cover. The ice fails in flexure under the weight of the excavator. It is small enough to be transported over road from site to site on a flat bed trailer. In ice that averaged 40 to $50 \mathrm{~cm}$, the Amphibex was able to break about $0.2 \mathrm{ha} / \mathrm{hr}$ (Haehnel et al. 1995).

\section{Ice bridging}

The previously discussed mechanical methods have all focused on weakening or removing the ice cover. Ice bridging is a mechanical methods that is used to change the way in which ice in a particular reach is formed or control the flow of ice into a problem reach (Fig. 13). An ice bridge is formed by cutting or breaking a large ice floe out of an intact ice cover (or border ice) and then plac- ing it across the river to artificially create a blockage; hence, the ice bridge is used in much the same fashion as an ice boom.

At the outlet to Soo Harbor an ice bridge is used to prevent ice from interfering with the Sugar Island ferry crossing on Little Rapids Cut* (Fig. 13a, Little 1996, Tuthill 1996). Historically, the ice from the Soo Harbor would jam on the lower end of the Little Rapids Cut and cause ice to back up to the ferry crossing. By placing an ice floe at the entrance to the Little Rapids Cut, ice from the Soo Harbor does not enter the cut and ferry operation is unimpeded by ice.

Figure $13 \mathrm{~b}$ shows another use of an ice bridge: forming an ice cover over rapids (U.S. Army 1982). Quite often river rapids remain open all winter. Though an ice cover is not formed in this reach, the water is continuously exposed to subfreezing air temperatures that create tremendous amounts of frazil ice over the course of the winter. In slower downstream reaches the frazil ice forms hanging dams and freeze-up ice jams. To stop the production of frazil ice in these rapids, border ice is broken or cut from the shore and then placed diagonally across the river. Drift ice and frazil from upstream is halted by this barrier and freezes into a solid ice cover.

An interesting application of this method is

*Personal communication, J.K. Little, U.S. Coast Guard, Sault St. Marie, Michigan, 24 May 1996. 


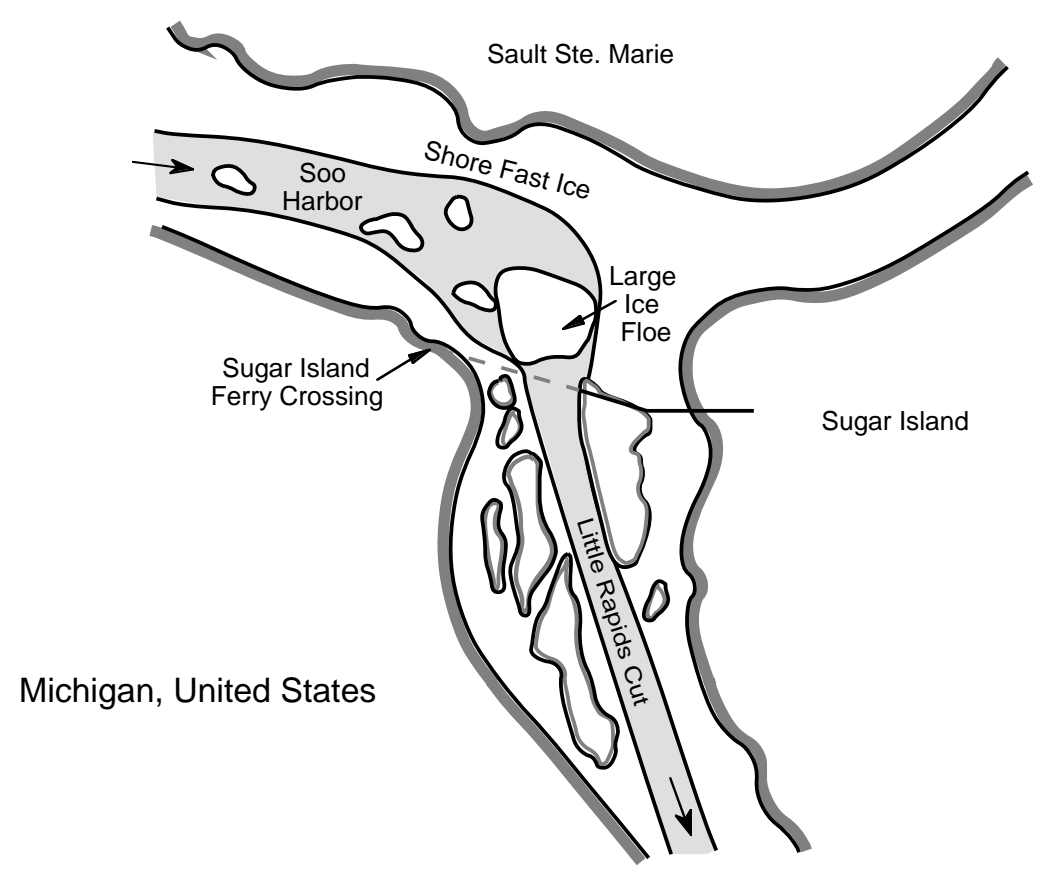

a. Ice floe used to block ice from entering Little Rapids Cut.

River Bank

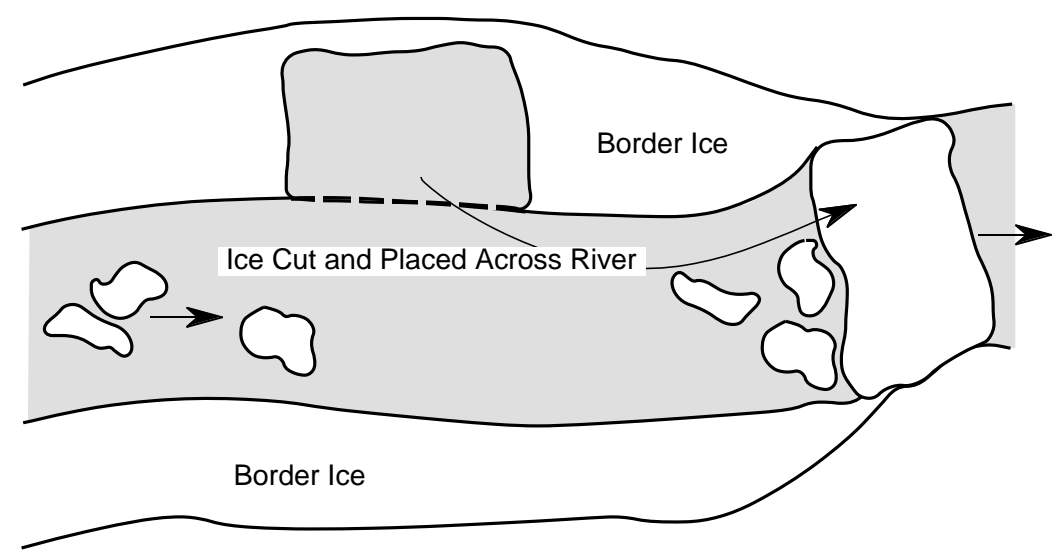

$b$. Border ice cut from the shore and used to initiate an ice cover in a reach of rapids.

Figure 13. Examples of ice bridging.

used on the Lule River in northern Sweden (Billfalk 1984). Frazil ice generated on the section of rapids below the Vittarv Power Station created hanging dams and freeze-up jams that caused flooding of residences and pump stations along the river. Additionally, the rise in the tailwater reduced the head for the Vittarv power station by as much as $2 \mathrm{~m}$ (cutting the head by a third). An ice boom spanning the Lule River was installed downstream of the power station to form a stable ice cover over the rapids. Though the boom worked well for creating a cover above it, an extensive section of rapids below the boom remained open and generated enough frazil to still cause flooding. Consequently, the boom was redesigned with a removable section to allow passage of ice 
floes to the downstream rapids. The sheet ice at the downstream end of the rapids forms a natural ice bridge that stops the floes. Over time the floes form a fragmented ice cover over the entire rapids from the downstream cover to the boom. To speed up the formation of the cover through the rapids, ice was cut from the shore above the boom and floated into the rapids. Once the rapids were covered with ice, the boom was closed. This combination of ice bridging and use of an ice boom was successful in stopping the frazil ice production along this reach of the Lule. This is an excellent example of combined use of structural and nonstructural techniques to achieve the desired result.

\section{THERMAL}

Ice cover deterioration results from weakening and melting the ice cover due to absorption of available thermal energy (Fig. 14). Energy exchange at the ice-air surface is driven by air temperature, wind velocity, humidity, available shortand long-wave radiation, and albedo. At the ice and water surface, the energy exchange is driven by water temperature and velocity. Thermal weakening methods use available thermal energy to retard the growth or accelerate the deterioration of the ice cover by manipulating the absorption of thermal energy from one or more of these sources.

\section{Suppression of ice growth}

One way to reduce the risk of ice jam formation is to reduce the volume of ice available to jam.
This can be done by breaking the ice and removing it from the problem reach prior to the spring freshet, as was previously discussed under mechanical advance measures. Alternatively, measures can be taken to inhibit the growth of ice throughout the winter. Generally the methods used to accomplish this have focused on increasing the temperature of the river water by routing of available thermal sources. Two basic sources that have be used are thermal effluent and warm water from lake bottoms.

The effect that suppressing ice growth has on wintertime operation can be seen at two U.S. Army Corps of Engineer projects, Lock and Dam (L\&D) 14 on the Upper Mississippi River and Dresden Island L\&D on the Illinois River. Both projects report considerably reduced ice problems because of power plants located upstream that discharge warm water into the river. To illustrate, on 5 December 1991 ice conditions on the Upper Mississippi stranded a tow pushing barges between L\&Ds 15 and 16. That evening an ice jam formed on the pool of L\&D 15 that brought river navigation to a standstill. It took 3 days for tows to break up the jam so shipping could resume. Meanwhile, only $17 \mathrm{~km}$ upstream L\&D 14 was experiencing no ice problems. The warm water discharge from a nuclear power plant located about $40 \mathrm{~km}$ upstream of L\&D 14 significantly reduces the volume of ice produced above the project, resulting in open water or slight skim ice on the pool during much of the winter months.

Ice jam hazards can also be reduced by accelerating the decay and melt-out of the ice cover so that the ice present is either too weak or of insuffi-
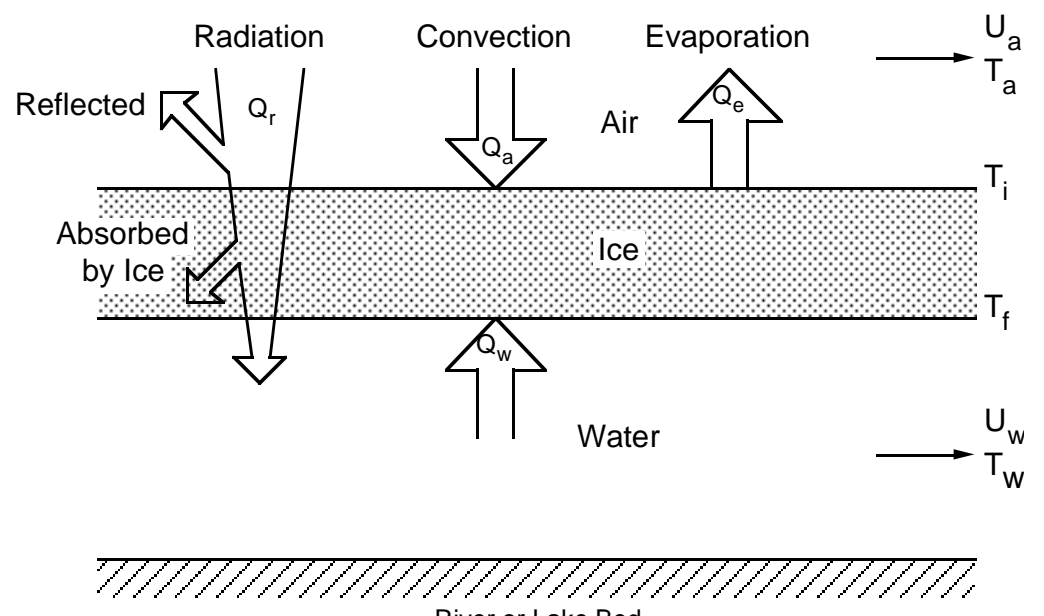

River or Lake Bed

Figure 14. Various sources of thermal energy available for deteriorating and melting an ice cover. $Q$ refers to the heat flux, $U$ is velocity, and $T$ is temperature. 
cient volume to form a jam. According to Prowse et al. (1990a) the strength of the ice is inversely proportional to the ice temperature. During midwinter conditions, the top surface of a snow-free ice cover is at or near the ambient air temperature $\left(-10^{\circ}\right.$ to $\left.-20^{\circ} \mathrm{C}\right)$ while the bottom of the ice is at the freezing temperature. During the spring, the entire ice cover warms and becomes isothermal throughout its thickness at the freezing temperature. Though weakened from midwinter conditions, solid ice at its freezing temperature still retains $50 \%$ or more of its original strength, as determined from flexural strength measurements on columnar lake ice (Ashton 1986, Prowse et al. 1990a). Prowse et al. (1990a) shows that further weakening of the ice cover is a result of the increase in ice cover porosity, which can reduce the ice strength to less then $10 \%$ of its original value. Once the ice becomes isothermal, as additional heat is added, melting of the ice takes place at the grain boundaries of the ice crystals, creating a porous ice cover with little loss of overall ice thickness. In addition to losing strength, the ice cover thins due to warming air and water temperatures. If the spring freshet occurs after the ice has been allowed to rot naturally in place, there is little threat of jam formation. Often the spring freshet occurs before the ice has undergone much weakening or loss of volume, which can lead to ice jam formation and flooding. Acceleration of ice deterioration has been accomplished principally by routing of warm water sources and increasing radiation absorption.

Below are discussed some of the methods used to modify the thermal regime of the river to suppress ice growth or advance ice deterioration.

\section{Routing of warm water}

\section{Thermal effluent}

Thermal effluent is available from a variety of sources, including power plant cooling water, sewage, and ind ustrial discharge (Bolsenga 1968, Paily et al. 1974, Ashton 1979). Obvious benefits are realized from open circuit cooling of coal and nuclear fired power plants, which take water from the river to cool the plant and then deposit the warm water back into river (e.g., reduced ice problems experienced at L\&D 14 on the Upper Mississippi River discussed above).

Cooling ponds for power plants are a ready source of thermal energy that can be used to retard ice growth or advance melting in the spring. For example, ice from the Kankakee River fre- quently jammed at the confluence with the Illinois and Des Plains River, flooding the City of Wilmington, Illinois. During the period from 1935 to 1986 ice jam floods occurred on the Kankakee in Wilmington, or outlying communities, 26 out of 52 years, and in 1982 alone damages totaled over $\$ 10$ million (Deck 1986). Furthermore, the ice released from the Kankakee River threatened the structural components of Dresden Island L\&D; in 1982 two of the dam gates had to be replaced due to structural damage caused by ice released from the Kankakee.* The Kankakee River ranges in width from $150-300 \mathrm{~m}$ and has a wintertime flow of $110-140 \mathrm{~m}^{3} / \mathrm{s}$. In 1987 a siphon system was installed in the cooling pond of the Dresden power station, which is adjacent to the Kankakee River, to route warm water from the pond to the river (Fig. 15). The siphon was located about $7 \mathrm{~km}$ upstream of the confluence with the Des Plains and Illinois Rivers. Three pipes, $0.75 \mathrm{~m}$ in diameter, brought a total of $3.1 \mathrm{~m}^{3} / \mathrm{s}$ of $6^{\circ} \mathrm{C}$ water from the cooling pond to the river. Two of the pipes discharged on either side of the river, and the third pipe discharged in the middle of the river. During operation in January of 1988, the siphon was able to open $4 \mathrm{~km}$ of river after operating a week. Within two weeks of operation the river was clear of ice from the siphon outlet to the confluence with the Illinois. The plot at the top of Figure 15 shows the water temperature in the river on 18 January 1988 shortly after the siphon started operating.

Where possible ice problems can be reduced by location of thermal sources near problem reaches. However, usually ice problems on nearby rivers are not considered in design and location of power plants or other industrial plants that could be used as a thermal source. Thus, retrofitting of current plants may be required to take advantage of available thermal energy. Where direct discharge of thermal sources into rivers is not environmentally acceptable (e.g., industrial gray water), heat exchangers may be employed to transfer the heat from the thermal source to river water. Also, routing of thermal sources over land via long penstocks to a problem area could be used, though the transit distance would be limited by the cooling of the water in the penstock.

\footnotetext{
*Personal communication, R. Chapman, Lockmaster, U.S. Army Corps of Engineers Rock Island District, Dresden Island Lock and Dam, Morris, Illinois, 1992
} 


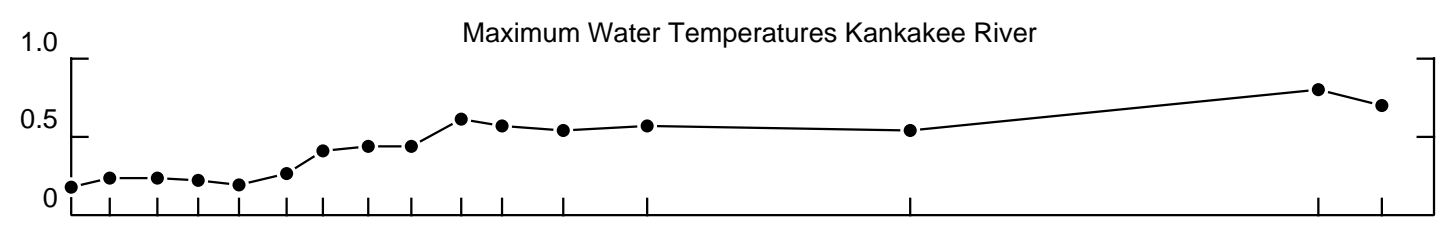

o Water Temperature Measurement Locations

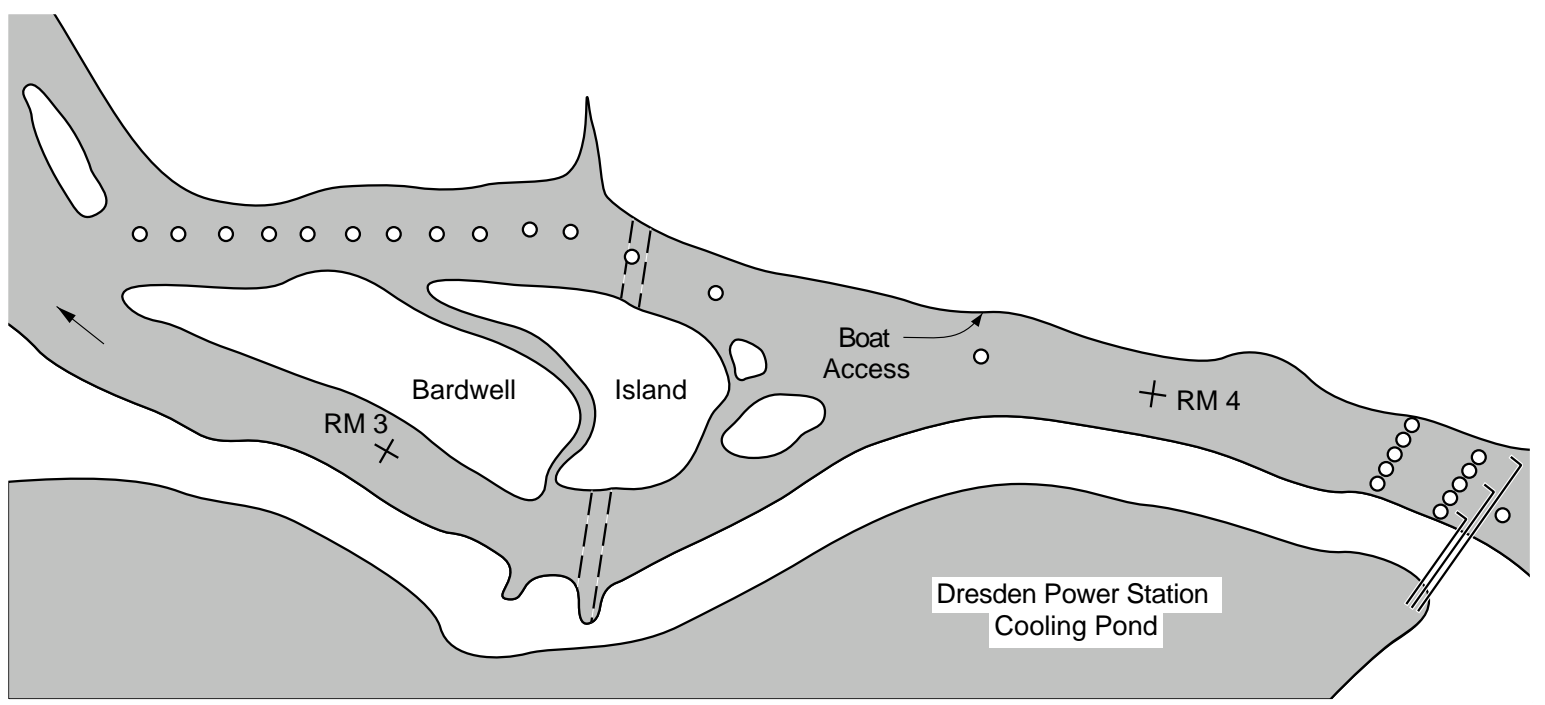

Figure 15. Siphons used to route warm water from the Dresden Power Station Cooling Pond for melting ice in the Kankakee river, Wilmington, Illinois. The plot shows the water temperature at various river sections downstream of the siphon outlets during operation on 18 January 1988 (after Gooch and Deck, undated).

\section{Natural sources}

Low grade thermal sources, such as lake bottoms, can also be used to melt ice or suppress ice growth. This warm water store is present because water reaches its maximum density at $4^{\circ} \mathrm{C}$; thus in a quiescent body of water, such as a lake, the water becomes stratified with the warm dense water residing on the bottom, and the colder water (and ice) floating on top. Depending on the depth of the reservoir the water can be as warm as $4^{\circ} \mathrm{C}$ at the bottom (Ashton 1982). If this water is brought to the surface it can be used to retard ice growth during the winter months, or advance ice melting in the spring. Desired results can be obtained with water as cold as $0.2^{\circ} \mathrm{C}$ (Ashton 1982). A possible way to accomplish this is to draw all of the outflow off the top of the reservoir during winter months. The less dense incoming cold water from the source river will remain on the top of the reservoir, and drawing the water off the top will result in discharge of only the cold water, preserving the warm water until spring. During the spring, the outflow can then be drawn off the bot- tom and used to hasten melting of the ice in the outlet river (Ashton 1982).

Use of warm water at lake and harbor bottoms has been routinely used to prevent ice damage to docks, marinas, and dam structures by bringing the warm water to the surface to melt the overlying ice. Transfer of the warm water to the surface is principally accomplished using bubblers and flow inducers (an electric motor with a propeller mounted in the front). With bubblers the warm water is brought to the surface in a plume of rising air bubbles released from orifices located in the warm water reserve (Fig. 16). Compressed air is delivered to an orifice (or manifold) on the lake bottom via an air line, the warm water becomes entrained in the rising air plume and is brought to the surface. This same effect can be accomplished using submersible water pumps or flow inducers (both of which will be collectively be referred to as flow inducers). However, the flow characteristics of a (Ashton 1982)

"bubbler-driven plume is different than that of a 


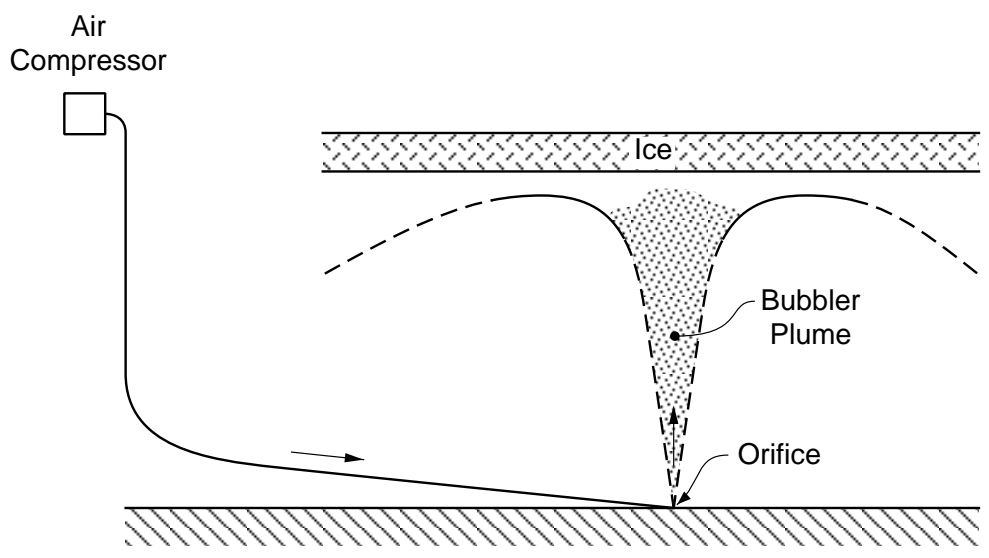

Figure 16. Schematic of a typical bubbler system.

submerged jet of water directed upward. In the former case the velocity of the plume is more or less constant with distance above the bubble source ... in the latter case the maximum velocity decays downstream of the pumping source .... Since the rate of melting is approximately proportional to the product of the water velocity against the ice undersurface and the temperature (above freezing) of the water, a pump located too far from the ice may produce little effect on the ice cover."

Thus, the outlet of the flow inducer must be very near the ice surface (Ashton 1982). Nevertheless, flow inducers can be effective at keeping large areas of water open. Michel (1971) reports a $7.5-\mathrm{kW}$ unit was capable of creating an opening in the ice that was about $1.5 \mathrm{~m}$ wide and $30 \mathrm{~m}$ long in air temperatures down to $-29^{\circ} \mathrm{C}$, and a $550-\mathrm{W}$ flow inducer was able to open an area about $12 \times 10 \mathrm{~m}$.

Though bubblers and flow inducers are effective at transferring warm water from the bottom of a lake or reservoir to suppress ice growth, they are of little use in rivers with velocities over $0.4-$ $0.6 \mathrm{~m} / \mathrm{s}$, since the water is quite often already fully mixed and the water temperature is typically less than $0.1^{\circ} \mathrm{C}$. Furthermore, any available warm water is already warming ice through existing current flow, and bubblers or flow inducers cannot enhance this heat transfer. However, frequently ice jams form at the confluence of a river with a lake or reservoir. In such areas bubblers and flow inducers can be effectively used to remove the ice cover in the receiving reach prior to the spring freshet; however, the author is not aware of any attempts to prevent ice jam flooding by this method.
Another method under development that may prove effective at suppressing ice formation or advance melt-out of ice was tested in the spring of 1996 at Oshawa Harbor, Ontario, Canada. This 7.5-m-long floating wave maker was effective at clearing a thin ice cover from a 15-m-wide and 80$\mathrm{m}$-long section of the harbor. ${ }^{*}$ The wave maker is a corkscrew-shaped roller supported by pontoons. The roller, rotated by a 186-W electric motor, creates a train of waves $15 \mathrm{~cm}$ high and about $1.2 \mathrm{~m}$ long. The waves not only increased the surface velocity but also advects warm water from as deep as half the wave length to the surface thereby suppressing ice growth (Andersen and Allyn 1984, Hindley 1996). For this prototype the mixing depth would only be about $0.6 \mathrm{~m}$, so if this were to be used for suppressing ice growth or melting ice a larger unit would need to be employed that extended the mixing depth to several meters. More field trials of this concept are planned.*

\section{Increasing solar absorption}

\section{Surface albedo reduction}

Snow and white ice have surface albedos in the visible light spectrum ranging from $50-90 \%$ and 60-80\%, respectively (Colbeck 1988, Prowse and Demuth 1992). In contrast, "black" or clear ice has an albedo of about 20\% (Prowse and Demuth 1992). Thus, for all but bare black ice, much of the incident solar radiation is reflected off the snow or ice surface. Reducing the surface albedo of the ice or overlying snow increases the solar (short-

*M. Maher, Personal Communication, Golder and Associates, Ontario, Canada, 1997. 
wave) radiation absorbed and accelerates the rate of melting and deterioration of the ice cover. One way to accomplish this is by spreading a dark material on the surface (commonly referred to as dusting). Dusting has been used extensively in North America, Europe, and northern Asia to weaken ice prior to icebreaking operations, advance the opening of harbors and waterways, and prevent ice jams. Some materials that have been used for dusting include sand, fly ash (or bottom slag), coal dust, dyes and pigments, carbon black, petroleum fuels, and leaves (Arnold 1961, Williams and Gold 1963, Williams 1967, Cook and Wade 1968, U.S. Army 1968, 1979, 1994, Cavan 1969, Slaughter 1969, Moor and Watson 1971, Haehnel et al. 1996).

The following properties are important to consider when selecting a material for dusting (Bonin and Teichmann 1949, Antrushin 1965):

- Absorptivity, $A$

- Thermal conductivity

- Density, $\rho$

- State of aggregation (solid vs. liquid)

- Particle size (if solid)

- Viscosity (if liquid)

- Freezing point (if liquid)

- Toxicity and environmental compatibility

- Solubility.

The absorptivity is a measure of the amount of radiation absorbed by the material and is simply

$$
A=1-\alpha
$$

where $\alpha$ is the albedo of the material. The absorptivity should be greater than that of the ice/snow surface. The average albedo* of some materials that have been used for dusting is shown in Table 1. The thermal conductivity relates to the ability of the material to transfer heat to the ice or snow. In general the thermal conductivity should be high. The density determines whether the material will float in the meltwater or remain on the ice surface; the material should have a specific gravity greater than one. The state of aggregation, particle size, viscosity, and freezing point all affect the type of equipment used to spread the material. Small particle sizes are preferable since they are readily handled in conventional crop dusting and spreading equipment. Low viscosity fluids can be readily applied with many available spray systems. Fluids that have a freezing temperature below the ambient air temperature can complicate application by freezing in the spray systems. As a minimum the freezing point of any liquid considered should be below that of water; otherwise the material will be thickening the ice and possibly be acting as an insulator over the ice surface. The material should be nontoxic to simplify handling of the material and avoid detrimental effects to aquatic life, animals, and humans that use the waterway. Furthermore, the environmental impact of introducing of fine foreign matter into a river

*This is the average albedo over the visible range of light.

Table 1. Average albedo values of various surfaces and dusting materials.

\begin{tabular}{|c|c|c|}
\hline Surface & $\begin{array}{c}\text { Average } \\
\text { albedo } \\
(\%)\end{array}$ & References \\
\hline New snow & 90 & Colbeck 1988 \\
\hline Old snow & 50 & Colbeck 1988 \\
\hline White granular ice & $60-80$ & Prowse and Demuth 1992 \\
\hline Black ice & 20 & Prowse and Demuth 1992 \\
\hline Water-covered ice & $20-30$ & Williams 1967 \\
\hline \multicolumn{3}{|l|}{ Material } \\
\hline Coal dust & $2-5$ & Haehnel et al. 1996 \\
\hline Lamp black pigment & 3 & Bonin and Teichmann 1949 \\
\hline \multicolumn{3}{|l|}{ Cobalt blue pigment } \\
\hline$\left(\mathrm{Co}_{2} \mathrm{O}_{3}\right)$ & 3 & Bonin and Teichmann 1949 \\
\hline Sand & 10-12 & Haehnel et al. 1996 \\
\hline Dry dead leaves & 20 & Haehnel et al. 1996 \\
\hline Bark dust & 20 & Haehnel et al. 1996 \\
\hline Red pigment $\left(\mathrm{Fe}_{2} \mathrm{O}_{3}\right)$ & 26 & Bonin and Teichmann 1949 \\
\hline
\end{tabular}


reach needs to be considered as well. For example, if fine material is not indigenous to the river, it may interfere with the reproductive cycles of some aquatic life (Haehnel et al. 1996). Finally, the material should be insoluble in water to avoid the need for reapplication due to dilution by meltwater. Other considerations include the availability and cost of the material, as well as the cost of application.

The amount of albedo reduction of the snow or ice surface achieved by dusting is a function of the albedo of the dusting material and the amount applied. Williams and Gold (1963) found that the albedo of the ice surface decreased nearly linearly with increasing application density $w$ (mass of material applied per unit area) up to some optimal $w$ at which point the surface albedo remained constant. An empirically developed relationship to determine the optimum application density for a given dusting material is

$$
w=2 / 3 C_{\mathrm{m}} \rho d
$$

where $C_{\mathrm{m}}$ is a constant for a given dusting material, and $d$ is the average particle diameter (Williams and Gold 1963). For Ottawa Valley crushed limestone, Williams and Gold (1963) found $C_{\mathrm{m}}=$
0.21 (Fig. 17). Though, in principle, $C_{\mathrm{m}}$ should be determined for each type of dusting material, 0.20 can be used in general and can give satisfactory results. In any event, material should never be applied in a thick layer to the ice or snow surface, since this will result in insulating the surface and shielding it from solar radiation. Application densities of 200 to $700 \mathrm{~g} / \mathrm{m}^{2}$ are generally used and lead to reduction in surface albedo from $50-70 \%$ to about 10-20\% (Williams 1967, U.S. Army 1968, 1979, 1994, Cavan 1969).

Equation 6 also points out the relationship between the application density and particle size. For a given dusting material, there is an inverse relationship between particle size and the resulting surface albedo, once the material is applied to the ice or snow surface. Thus, the smaller the particle size, the less material that is needed to reduce the surface albedo. Of course, the size of the particle must be balanced with other considerations as well; for example, particles must be of such a size and density that they will not be blown away by wind or washed off by meltwater. The effects of wind are particularly important if the material is to be applied by aerial crop dusting equipment. Experience has shown that particle size should range from 0.1 to $3 \mathrm{~mm}$ for best results (Spetsov

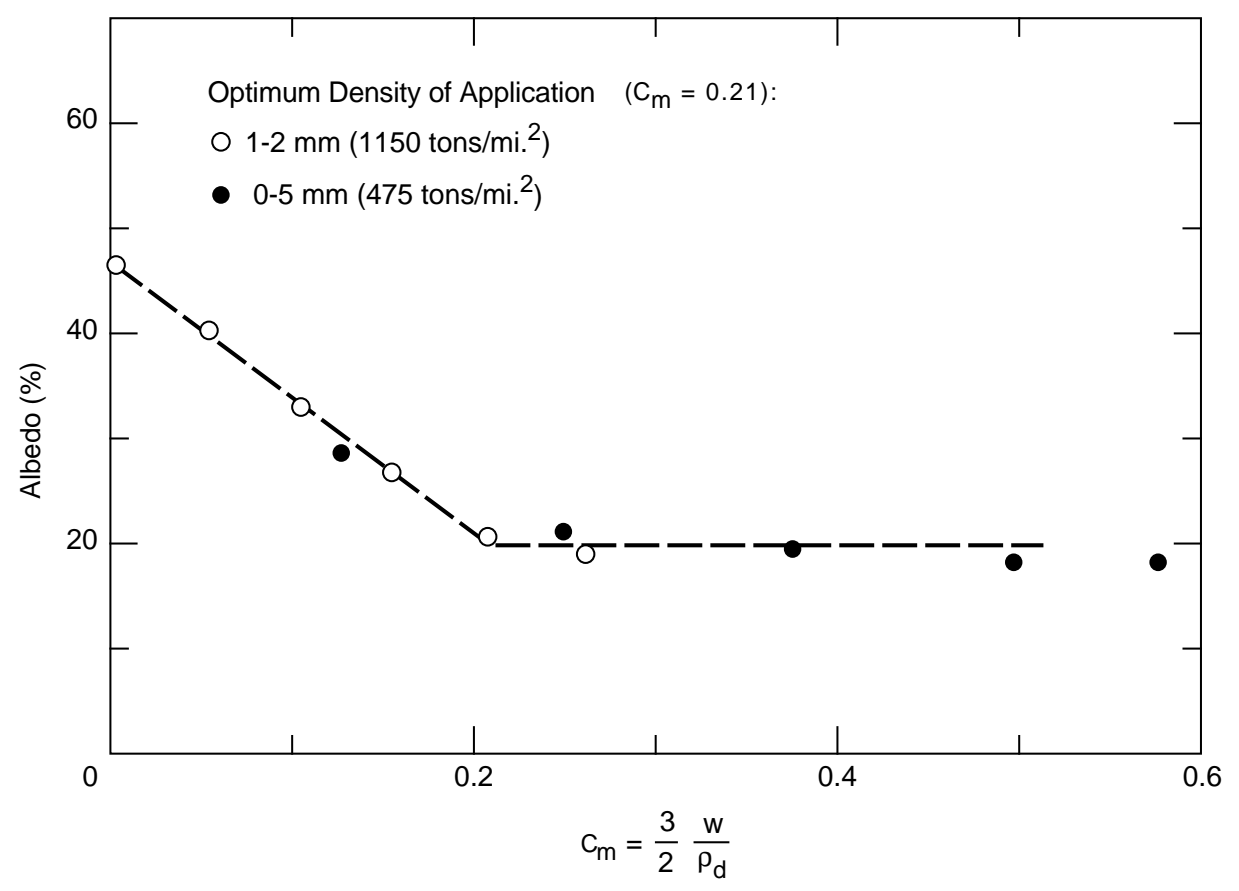

Figure 17. Albedo as a function of application density for Ottawa Valley crushed limestone applied to an ice surface (after Williams and Gold 1963). 
1965, Arnold 1961, Williams and Gold 1963, Cavan 1969).

Reducing particle size appears to offer advantages in addition to reducing the amount of material that needs to be applied. According to Spetsov (1965) particles in the range of 0.25 to $0.5 \mathrm{~mm}$ penetrated more rapidly into the ice surface than did particles greater than 1-2 mm (in this work coal dust, phosphate flour, and black pigment were used as dusting materials). Given sufficient time and favorable weather, these small particles would penetrate through an entire ice cover that was as much as $1 \mathrm{~m}$ thick, leaving behind an ice that was severely weakened and honeycombed. Meanwhile, particles that were $0.5-1 \mathrm{~mm}$ in size did not penetrate farther than 25 to $30 \mathrm{~cm}$, and particles greater than 1-2 mm remained on the ice surface. Spetsov points out that it is an advantage to have a range of particle sizes in the mix, since the large particles that remain on the surface reduce the surface albedo and accelerate the melting of snow that has fallen on top of the cover after the surface has been dusted.

In general dusting of a snow surface can increase the melt rate of snow by a factor of 10-15 (Bolsenga 1968). The dusted snowpack quickly becomes saturated with meltwater and consolidates because of the increase in solar energy absorbed. Cook and Wade (1968) point out that a cold snap will freeze this consolidated snow cover solid, and when this happens the undusted snow will melt more rapidly upon return of warm weather.

Dusting's greatest advantage appears to be its ability to weaken an ice cover (rather than reduce the thickness) and to accelerate removing an overlying snow cover, thereby exposing the underlying ice cover to solar radiation sooner (Spetsov 1965, Bolsenga 1968). Nevertheless, reductions in ice thickness of 1 to $6 \mathrm{~cm} /$ day in dusted areas, vs. undusted areas, have been observed, which can lead to advancing the melt-out of ice by as much as 6-10 days (Arnold 1961, Bolsenga 1968, Slaughter 1969).

In general, dusting operations should be carried out about 1 month before the historical iceout date. Since little melting occurs before the average air temperature reaches -2 to $0^{\circ} \mathrm{C}$ (Bonin and Teichmann 1949, Williams, 1967), there is no advantage to dusting much earlier than this. Thus, in regions where the river breakup is a result of a sudden thaw following a period of extreme cold, dusting will not be effective. Furthermore, since snow depths greater than 18 to $20 \mathrm{~cm}$ will block most of the radiation before it reaches the underlying dusting layer (Arnold 1961, Prowse et al. 1990b, Haehnel et al. 1996), timing of the dusting operation should be such that the bulk of the snowfall has ended for the season. Snowfall of more than $20 \mathrm{~cm}$ will necessitate a reapplication of the dusting material.

The most widely used method of applying dusting materials has been aerial crop dusting equipment (Antrushin 1965, U.S. Army 1968, 1979, 1994, Bolsenga 1968). Other methods include dusting by hand, pumping sand from the river bottom unto the ice (Moor and Watson 1971) and using a hydroseeder (Haehnel et al. 1996). Aerial dusting is relatively inexpensive and allows quick coverage of large areas (Fig. 18a). To prevent clogging the crop dusting equipment, the dusting material needs to be dried prior to loading. Spreading the material while it is still hot from the dryer has the advantage of causing the material to melt into the ice a small amount immediately after application, which makes the material less susceptible to being redistributed by winds. Typically a swath of material about $9-15 \mathrm{~m}$ wide is laid down by a single flyby.

Pumping of river bottom sand and silt has the advantage of not introducing foreign materials to the river reach. Also the wet slurry is not susceptible to redistribution by the wind. However, extracting the material from the river bottom disturbs the aquatic habitat and as such may not be environmentally acceptable.

Use of the hydroseeder has proven to be a lowcost way to apply dusting in heavily populated areas or on narrow rivers that would be difficult to dust using aircraft. In this case, a slurry of the dusting material and water is stored onboard the hydroseeder truck. The easiest way to dust using this method is to spread the slurry with the cannon mounted on the deck of the truck (Fig. 18b). However, this requires there be easy access to the river (i.e., a parallel road running along side the river). The range of application can be extended using the onboard 120-m hose to reach less accessible areas (Haehnel et al. 1996). Though the hydroseeder has been tried using only leaf mulch, it is likely that other materials could easily be spread using this method as well.

In a typical dusting operation the objective is not to cover the entire ice surface, but rather to create lines of weakened ice for the ice cover to fail along, much in the same way ice cutting is used to weaken an ice cover. Typically one or two lines of dusted material are laid down parallel to the 


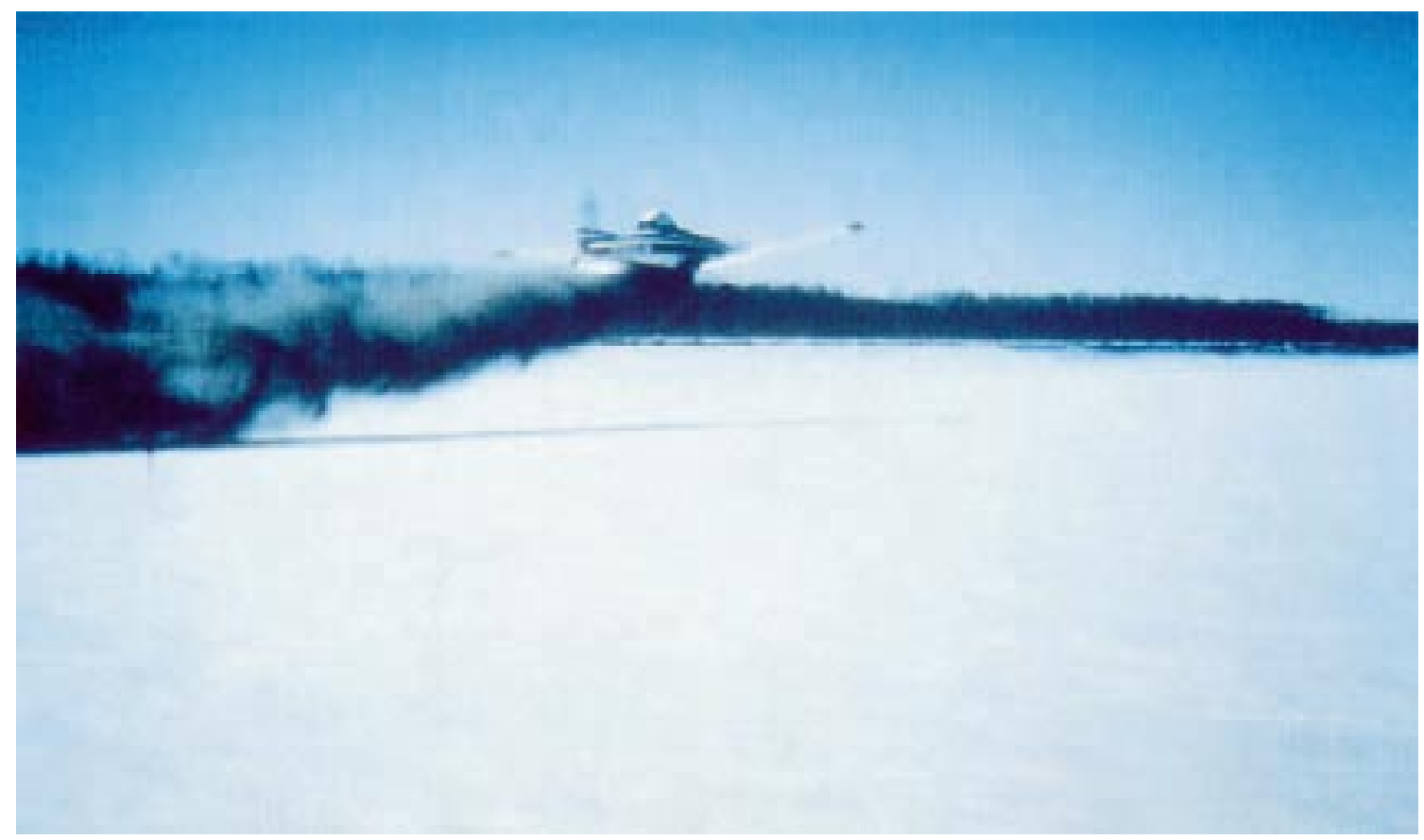

a. Crop dusting aircraft.

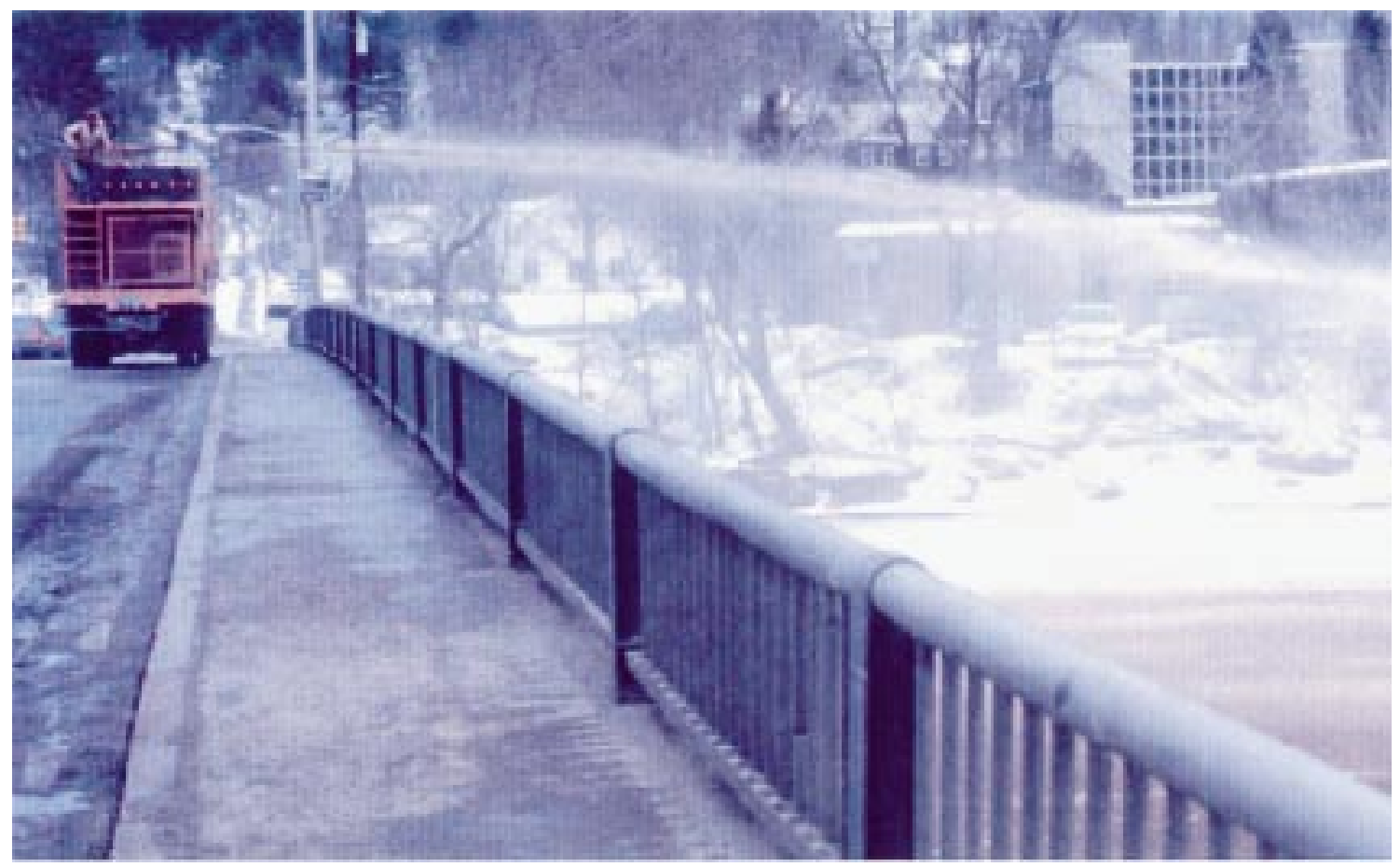

b. Hydroseeder.

Figure 18. Equipment used for dusting. 
river banks, preferably over the thalweg. Crossing patterns may be laid down over the longitudinal line as well. The resulting pattern leads to the breakup of the ice cover into small floes the are about half the river width.

Success of dusting is highly dependent on prevailing weather conditions, and the availability of sunlight. Heavy snows, snowdrifting, or persistent overcast conditions can render a dusting operation ineffective. For example, dusting operations had been carried out annually since 1968 on the Yukon River from Galena, Alaska, to Bishop Rock, a distance of $20-30 \mathrm{~km}$. In this operation the only the snow-covered ice was dusted, leaving the bare ice undusted. Prior to dusting, the city of Galena had been flooded nearly annually. With dusting, the incidence of flooding was severely reduced, but there were still several floods during the 25 years of dusting. Nevertheless, experience on the Dvina and Onega Rivers in Europe (Bolsenga 1968) and the Yukon River in Alaska* indicates that dusting greatly reduces the severity of ice jam flooding.

\section{Ice flooding}

Water on the top of an ice cover has an albedo of about $15 \%$ while white ice has albedo values of $60-80 \%$ (Prowse and Demuth 1992). Thus flooding the ice cover with water can increase the absorption of solar radiation at the ice surface. However, Wake and Rumer (1979) point out that since water can be considerably warmer than $0^{\circ} \mathrm{C}$ evaporative cooling is increased, and longwave radiation input and heat transfer are reduced due to reductions in the temperature difference between the surface and air. Thus, the benefits of flooding an ice cover may not be as great as a consideration of albedo reduction may imply. Nevertheless, if there is an overlying snow cover on the ice, the water will serve to accelerate the melting of the snow, provided air temperatures are at or above freezing. Tests conducted by Moor and Watson (1971) support this conclusion. In these experiments an ice surface was flooded by drilling 3.8$\mathrm{cm}$-diam. holes in ice, allowing water to flow unto the ice. Initially the water gushed out of the holes, flooding the ice and snow cover. Within 24 hours the snow around the holes had been depressed 5 $\mathrm{cm}$, yet by this time the holes had refrozen. This approach may still have merit if larger diameter

*Personal communication, M. Bird, Alaska Division of Emergency Services, Fort Richardson, Alaska, 1994. holes are used, which would prevent refreezing of the holes.

\section{Snow removal}

Ice decay can be accelerated by simply removing the snow layer that serves as an insulator as well as a reflector (Antrushin 1965, Williams 1967). In cases where the snow covers black ice, this alone will drop the albedo by $40 \%$ or more. Clearing of the snow surface can be accomplished using excavation equipment (e.g., bulldozers) or dusting.

\section{Controlling the type of ice formation}

Prowse and Demuth (1992) studied the decay in strength of river ice during spring thaw and found that an ice cover that is predominantly composed of columnar ice decays more rapidly than a "white" ice cover (small diameter grains composed of snow ice and frazil that is opaque in appearance). In this work, measurements of compressive ice strength using a borehole indentor were taken in adjacent areas of columnar and frazil ice covers over a 14-day period in April on the Liard River, Northwest Territories, Canada. During this period the compressive ice strength in the white ice stayed constant at about $17 \mathrm{MPa}$, while that of the columnar ice declined in strength from about $19 \mathrm{MPa}$ to $10 \mathrm{MPa}$. There are several reasons for this. First, columnar ice is often very flat on the upper surface and is easily swept clean of snow by wind, which exposes it to direct solar radiation. White ice often has a rougher surface texture, which helps to trap snow, acts as an insulator to warm ambient air, and reflects solar radiation. Second, columnar ice is often translucent or transparent. When this is the case, it is referred to as black ice, because it is dark in appearance and has a very low albedo in comparison to snow or white ice. Because of this low albedo, it readily absorbs large amounts of solar radiation, hastening its decay.

If it were possible to manipulate the type of ice that formed in a given river reach, this might be another way to reduce ice jam threat by making the ice more susceptible to radiation decay, and thereby advancing melt-out. However, the author is not aware of any attempts to manipulate the type of ice formed to reduce ice jam potential.

\section{CHEMICAL}

Use of chemicals to remove an ice cover has been used extensively in the former U.S.S.R. 
Table 2. Eutectic temperatures and volume of ice melted (per gram of salt with the ice at $-5^{\circ} \mathrm{C}$ ) for various salts (Michel 1971).

\begin{tabular}{lcc}
$\begin{array}{c}\text { Anhydrous } \\
\text { substance }\end{array}$ & $\begin{array}{c}\text { Eutectic } \\
\text { temperature } \\
\left({ }^{\circ} \mathrm{C}\right)\end{array}$ & $\begin{array}{c}\text { Volume } \\
\text { melted } \\
(\mathrm{cm})\end{array}$ \\
\hline Calcium chloride $\left(\mathrm{CaCl}_{2}\right)$ & -5.0 & 10.1 \\
Potassium chloride $(\mathrm{KCl})$ & -10.7 & 10.3 \\
Magnesium sulfate $\left(\mathrm{MgSO}_{4}\right)$ & -11.4 & 3.6 \\
Ammonium nitrate $\left(\mathrm{NH}_{4} \mathrm{NO}_{3}\right)$ & -16.9 & $\mathrm{~N} / \mathrm{A}$ \\
Sodium nitrate $\left(\mathrm{NaNO}_{3}\right)$ & -18.1 & 7.5 \\
Sodium chloride $\left(\mathrm{NaCl}^{2}\right)$ & -21.2 & 12.2 \\
Magnesium chloride $\left(\mathrm{MgCl}_{2}\right)$ & -33.6 & 9.6 \\
\hline
\end{tabular}

(Antrushin 1965, Bolsenga 1968, Michel 1971). The environmental impacts of putting large amounts of chemicals into a river or lake are typically unacceptable. Nevertheless, for completeness, a brief discussion of some of the chemical methods that have been used to reduce ice jam potential are summarized below.

In general the chemicals used are salts and thermochemicals. Salts depress the freezing point of water by dissolving into the water. The minimum temperature to which a saturated solution of the salt can depress the freezing point of water is the salt's eutectic temperature. At temperatures below the eutectic point, no melting occurs. Eutectic temperatures for some chemicals that have been used for melting ice are presented in Table 2. Also listed in Table 2 is the theoretical volume of ice that one gram of salt can melt when the ice is at $-5^{\circ} \mathrm{C}$.

To give an idea of the amount of salt required to carry out such an operation, Antrushin (1956) reports an application density of 3.5 tonnes/ha for sodium chloride is required to melt $10-\mathrm{cm}$ ice at a temperature of $-10^{\circ} \mathrm{C}$. Spetsov and Shatalina (1965) notes that this is most effective when it is applied in narrow strips much like in a dusting operation.

Thermochemicals produce heat when mixed together; thus the melting is a result of the exothermal reaction. Some of the chemicals that have been used include (Antrushin 1965, Michel 1971)

- Calcium chloride and unslaked lime.

- Powdered aluminum and copper vitrol.

- Powdered aluminum and sodium hydroxide.
Since the resulting chemical reaction can be quite violent, the chemicals are applied by separate passes of aircraft; the first aircraft carries one chemical and the second carries the other (Antrushin 1965). Michel (1971) reports that an application of powdered aluminum and sodium hydroxide melted over $1 \mathrm{~m}$ of ice in 2 days.

Chemical weakening has also been achieved by modification of the growing ice. Michel (1971) describes application of a "saphonated substance derived from fatty acids" that produced a weak ice cover that was "mushy and sponge-like."

\section{BREAKING ICE JAMS}

Up to this point the focus has been on ways to prevent ice jam formation by weakening or removing the antecedent ice cover before the spring freshet occurs. However, in many cases nonstructural methods are used to remove an ice jam that has formed. This section addresses some of the techniques that have been employed to breach a jam once it has formed. In many cases some of the same equipment and methods that are used to prevent a jam can also be used to break a jam, but breaching a jam is typically an emergency response that requires rapid mobilization of resources to minimize flood damage or navigation delays and avoid loss of life. Rapid response is best achieved when advance planning has been carried out to make sure the necessary equipment is available, personnel are trained and ready, and permits are in place.

\section{Blasting}

Blasting ice jams requires consideration of several factors that are not present when breaking level ice. First, in the few hours after a jam has gone into place, it is usually not stable enough to put personnel or equipment on the jam. However, during these first few hours, while the hydrograph is still on the rising limb, is the time that the blasting operation will have the greatest chance of success since there is still sufficient flow to clear the jam. Thus, placement of the charges has been done by helicopter or by throwing them from shore (Bolsenga 1968, White and Kay 1997). The blasting should proceed from the toe upstream into the jam. Second, for maximum effectiveness the charges should be placed below the water, but this may not be possible if the personnel cannot be put on the jam. If the charges cannot be placed under the jam, they should be placed as deep in the jam 
as is practical by putting them in naturally occurring holes and crevasses in the jam. Once the charges are placed, the best results are obtained when they are detonated simultaneously. In general the charge size should be about the same as given in eq 2-4, though the charge size might be slightly larger or spacing reduced to compensate for not being able to set the charge under the ice. Furthermore, the broken ice in the jam will also act to absorb much more energy than an unbroken cover, so spacing may need to be adjusted during the course of the operation to assure that the craters overlap.

Often jams form when broken ice encounters a stable, unbroken sheet ice cover. In this case removal of the sheet ice is sometimes sufficient to release the jam (Michel 1971). Under these conditions personnel may be safely put on the stable ice cover and charges placed under the sheet ice according to the guidance provided in eq 2-4.

If charges are placed by being thrown from the shore, the charge size will need to be greatly reduced to hurl them any distance. Charges of 2 to 3 $\mathrm{kg}$ thrown from the shore were used successfully to clear a channel $600 \mathrm{~m}$ long $\times 150 \mathrm{~m}$ wide in a jam on the Missouri River (Bolsenga 1968).

In rare cases only a few charges placed at the toe of the jam may be sufficient to break the "key" that is holding the jam in place, and will cause the release of the entire jam. This was the case for a jam that formed on the Walhonding River at Warsaw, Ohio, in January 1997 (Daly 1997). Two charges (about $2 \mathrm{~kg}$ each) placed at the toe of the jam were successful at releasing the entire 1-kmlong jam. More commonly though, extensive blasting is needed to break a jam. For example, a 3.3km-long jam that formed in February 1997 on the Platte River upstream of Ashland, Nebraska, required 5 hours and about $60,000 \mathrm{~kg}$ of explosives to break the jam (White and Kay 1997).

In this latter case the blasting operation commenced within 2-3 hours of jam formation, which appeared to be a decisive factor in the success of the operation. Contrast this with a blasting operation that was carried out on a jam that formed on the Platte River in 1993, also near Ashland (White and Kay 1997). An initial jam had formed in early February causing minor flooding. This jam remained after the flood waters receded and froze in place. This jam was then an obstruction for the spring ice breakup and caused a 6.4-km-long jam on 8 March, resulting in numerous levee breaches and extensive flooding. Blasting on this jam did not begin until the 16th of March. It took two days to blast a channel through the jam, which allowed the water levels to decrease, by which time extensive damages to farmland, residential property, highways, levees and utilities had already been sustained. A more rapid response, either in February to clear the initial jam or at the formation of the jam on 8 March, might have helped to reduce damages significantly.

\section{Towboats and icebreakers}

Towboats and icebreakers have been used extensively to break ice jams. Though icebreakers are better equipped to break jams, towboats often serve as "Johnny-on-the-spot" to handle ice problems that develop. Despite the type of vessel the basic strategy for breaking the jam is the same. As with blasting, the operation should start at the toe of the jam and work upstream. At least two vessels work together to break away ice masses from the central part of the jam (Bolsenga 1965, Michel 1971). Additional vessels may be on hand to patrol the loose ice and prevent further jamming downstream. This may be carried out in conjunction with blasting operations as well, with the prop wash from the vessel helping to clear blasted ice (Bolsenga 1968).

An example of icebreaking using towboats occurred on the upper Mississippi River at L\&D 15 during December 1991. As previously discussed the 4-km jam formed on 5 December halting river traffic. Towboats that were on site were pressed into service and were used to break the jam. The jam had formed on the pool behind the dam at L\&D 15. Two towboats worked in the shipping channel breaking away portions of the jam. Meanwhile, a third towboat was tied to the outer guide wall of the lock, and used its prop wash to flush the floating ice over the dam. Occasionally the passage to the dam would become blocked, and towboats would be dispatched to reopen the channel. Working close to the dam to clear such a passage is dangerous because if the jam broke and started moving it could push the towboat up against the dam. To protect against this, two towboats were tied together so, if the jam started to run, the combined power of the two boats would be sufficient to overcome the force of the driving ice and allow the towboats to move to a tether point while the ice passed. However, even this precaution is not guaranteed to work against a large jam. After three days, the jam finally broke loose and moved en masse over the dam.

Another technique for clearing ice was seen em- 
ployed at L\&D 19 in Keokuk, Iowa. The ice was cleared and directed toward the dam by tying two towboats together in a $\mathrm{T}$ shape, with one boat pushing the other like a plow. The resulting passage was much wider and less likely to become blocked by floating ice.

\section{Excavation}

Construction equipment have been used to remove jams as well. The type of equipment that has been used includes excavators, bulldozers, and dragline and clamshell buckets. Amphibious excavators have also been used in Canada to break ice jams on deeper rivers where conventional excavators cannot be deployed. Working from the downstream end of the jam, the excavators break up and remove the ice from the channel. Ideally the ice is piled on the shoreline. If this is not possible the ice may need to be removed from the river altogether and trucked away from the site.

A crane with an I-beam as a wrecking ball was used in the spring of 1992 to break up a jam on the Winooski River in Montpelier, Vermont. Working from the shore, the crane used the weight to break up a large floe at the toe of the jam, thereby releasing the jam.

An ice jam on Saranac River, near Plattsburg, New York, was removed during the winter of 1996 using a combination of excavation and blasting (White and Kay 1997). Ice at the toe of the jam was loosened using a backhoe working in the stream channel. The ice was then pushed to the side of the river using bulldozers. Once the channel was cleared to within $60 \mathrm{~m}$ of the upstream end of the jam, the excavation equipment was removed from the river and the remaining jam was removed using explosives. Working in the river channel raises concerns about safety, especially if the jam is unstable. Thus, this type of operation should only be carried out on a grounded jam that has little or no water behind it so there is no risk of it releasing while equipment or personnel are in the channel below the jam.

Ice jams have occurred almost annually on the Lamoille River in Hardwick, Vermont. Excavation equipment working from shore and off bridges is used to loosen the ice jams as they form, and keep the ice flowing through town. In this case it is a combination of experience and the rapid response of the town highway crew that prevents extensive jam formation and flooding in the town. However, the town of Hardwick has not always been successful at removing the jam before it becomes grounded and causes damage. Figure 19 shows excavation equipment working at Hardwick to remove a 2- to 3- m-thick grounded jam.

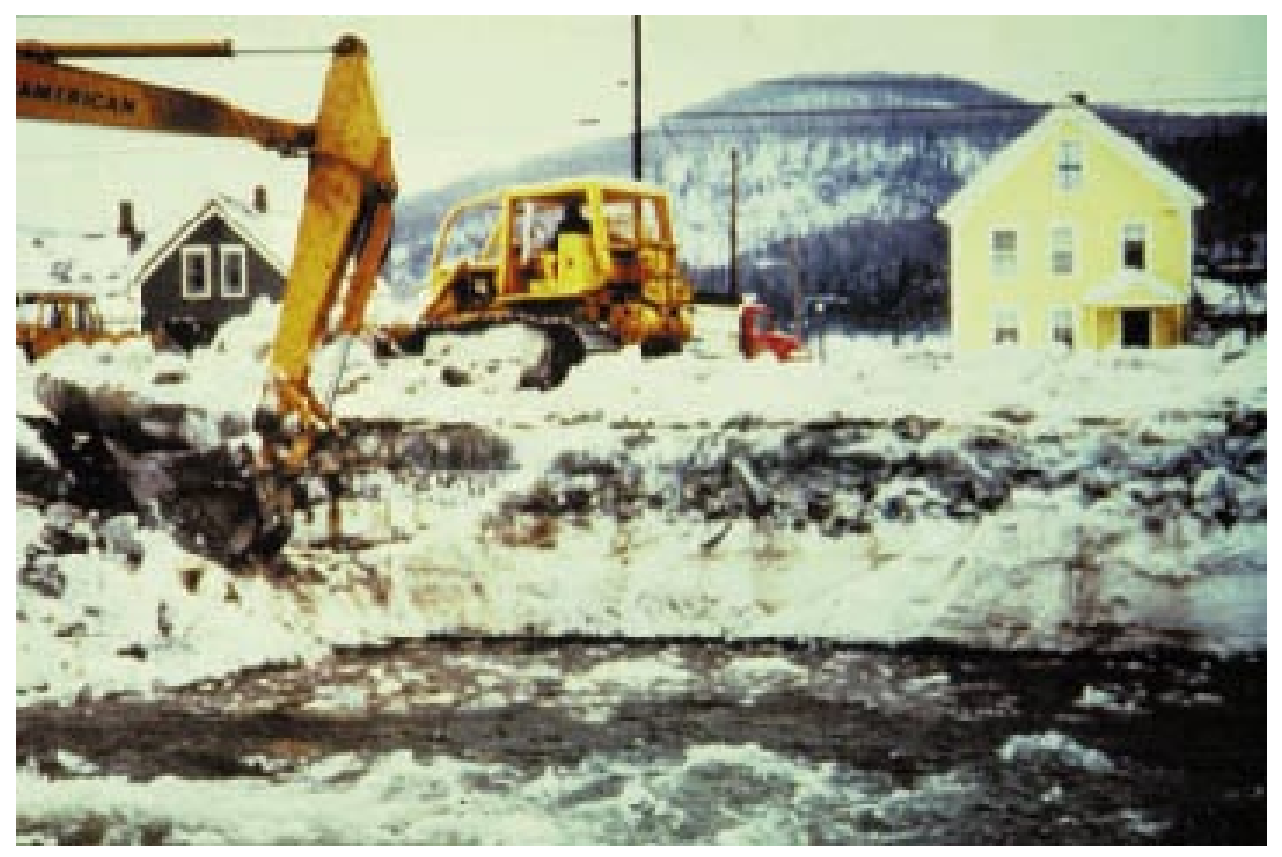

Figure 19. Breaching an ice jam in Hardwick, Vermont, using excavation equipment working from the shore and a bridge (bridge is not shown, but is just beyond the left edge of the photograph). 


\section{COST AND PERFORMANCE OF NONSTRUCTURAL MEASURES}

Available cost and performance information, in terms of ice destruction capability for the nonstructural methods discussed, is presented below. The fundamental differences in the nature of the methods presented make it difficult to do a direct comparison of the cost and performance between classes of methods. For example, when destroying ice via an icebreaker, reporting the cost of operation in terms of the area or volume of ice broken is reasonable. On the other hand, when weakening ice by cutting out large floes, it might be more reasonable to talk in terms of cost per lineal distance of trenches cut. Therefore, the cost and performance data has been compiled in terms of the basic nature of the operation.

A performance parameter that is commonly used is specific energy, $E$, which is the amount of energy required to remove/destroy a unit volume of material. Given $p$ is the rated power, and $\dot{V}$ is the volumetric material removal rate then

$$
E=p / \dot{V}
$$

Other cost and performance data are similarly presented in terms of unit of ice destroyed (e.g., cost/area of ice destroyed per unit time, etc.).

For ice cutting operations the cost and performance data are presented in terms of the volume of ice removed, which allows comparison independent of ice thickness and the kerf width of the tool. This information is presented in Table 3 in order of increasing specific energy. From Table 3 it is apparent that the mechanical cutters outperform the water and thermal cutters in terms of specific energy consumption and cost. Furthermore, the equipment that has been optimized for cutting ice, namely the channeling plow and the

Table 3. Cost and performance of ice cutting equipment. All costs are adjusted to 1996 U.S. dollars.

\begin{tabular}{|c|c|c|c|c|c|c|c|}
\hline Equipment & $\begin{array}{l}\text { Specific } \\
\text { energy } \\
\left(\mathrm{MJ} / \mathrm{m}^{3}\right)\end{array}$ & $\begin{array}{c}\text { Ice } \\
\text { removal } \\
\text { rate } \\
\left(\mathrm{m}^{3} / \mathrm{min}\right)\end{array}$ & $\begin{array}{c}\text { Maximum } \\
\text { ice } \\
\text { thickness } \\
\text { (m) }\end{array}$ & $\begin{array}{l}\text { Kerf } \\
\text { width } \\
(\mathrm{cm})\end{array}$ & $\begin{array}{l}\text { Cost } \\
\left(\$ / m^{3}\right)\end{array}$ & $\begin{array}{c}\text { Mobilization/ } \\
\text { demobilization } \\
(\$)\end{array}$ & References \\
\hline Channeling plow & 0.86 & 25 & 0.6 & NA & - & - & Tsykin 1982 \\
\hline Case DH4 & $3.2-6.4$ & $0.3-0.6$ & $>0.5$ & 15 & $6.90^{*}$ & 2,000 & Labbé 1983 \\
\hline GPI-41 & 5.5 & 0.57 & $>0.5$ & - & - & - & Tsykin 1982 \\
\hline Chainsaw for coal & 5.9 & 0.49 & 1.8 & 8.2 & - & - & Garfield et al. 1976 \\
\hline ICESAW & 6.7 & 1.5 & 1.2 & 19 & $0.98+$ & - & Mykkanen 1997b \\
\hline GPI trencher & $8.6-17$ & $0.3-0.6$ & 1.5 & 15 & - & - & Aleinikov et al. 1974 \\
\hline Chainsaw & 14 & 0.098 & 1.8 & 1.4 & - & - & Garfield et al. 1976 \\
\hline $\begin{array}{l}\text { Homelite } \\
550 \text { chainsaw** }\end{array}$ & $16-1$ & $0.012-0.014$ & 0.6 & & - & - & Coutermarsh 1989 \\
\hline Steam cutter & $29-72$ & $0.002-0.003$ & - & $15-20$ & $270.00+t$ & $5,00+t$ & Bojun and Si 1990 \\
\hline Ditchwitch 1620 & 35.7 & 0.020 & 1.2 & 12 & $33.00^{* * *}$ & 1,200 & Lever 1997t+t \\
\hline Watermaster & 38.9 & 0.23 & 0.5 & 8 & 1.10 & - & \\
\hline Water jet & $290-880$ & $0.01-0.03$ & 0.17 & $0.5-1.0$ & - & - & $\begin{array}{l}\text { Calkins and Mellor } \\
1976\end{array}$ \\
\hline Thermal & $400-530$ & - & - & - & - & - & Mellor 1984 \\
\hline Laser & 414 & - & - & - & - & - & Mellor 1984 \\
\hline
\end{tabular}

${ }^{*}$ Cost brought forward to 1996 US \$ using Consumer Price Index.

+Using a currency exchange rate for 1996, 4.5 FIM = \$1 US.

**Tested using a $0.6-\mathrm{m}$ cutting bar.

t+Estimated by author using cost for conventional steam cleaning equipment as basis.

***Does not include cost of snow blower.

t++Personal Communication, J.H. Lever, CRREL, 1997.

NA— not applicable. 
ICESAW, exhibit the highest ice removal rates. Nevertheless, in terms of specific energy, the unmodified Case DH4 is about equal with the ICESAW; thus, there is readily available off-theshelf equipment that can be used to cut ice efficiently. However, the fact that ICESAW, Watermaster, and Amphibex are amphibious does offer an advantage when the ice thickness is marginal.

The cost and performance for breaking ice, expressed in terms of area of ice cover destroyed, is presented in Table 4. Again the methods are listed in order of increasing specific energy. In terms of specific energy, air cushion vehicles (ACVs) are clearly the most efficient for breaking ice. However, it is not clear that ACVs are the least expensive method. For example, for maintenance alone
Robertson (1975) reports that the Voyageur required about 11 hours of maintenance per hour of service; in contrast, the AST-002 required about 1 hour of maintenance per 20 of hours service (Edworthy et al. 1982). In terms of cost, icebreaking vessels are clearly the least expensive way to break ice, though their use is limited by river depth.

The cost per covered area of dusting is presented in Table 5, where the methods are listed in order of increasing cost. No performance data are given for dusting since it is difficult to quantify directly. Though pumping appears to give the lowest cost, the author is unaware of use of this method beyond the initial work done by Moor and Watson (1971).

By far the most extensively used method is aerial dusting. From Table 5 it is apparent the cost

Table 4. Cost and performance of icebreaking methods. All costs are adjusted to 1996 U.S. dollars.

\begin{tabular}{|c|c|c|c|c|c|}
\hline $\begin{array}{l}\text { Method/ } \\
\text { Vessel }\end{array}$ & $\begin{array}{c}\text { Specific } \\
\text { energy } \\
\left(M J / m^{3}\right)\end{array}$ & $\begin{array}{c}\text { Cost } \\
\text { (\$/Hectare) }\end{array}$ & $\begin{array}{c}\text { Ice } \\
\text { thickness } \\
(m)\end{array}$ & $\begin{array}{c}\text { Destruction } \\
\text { rate } \\
(\mathrm{ha} / \mathrm{hr})\end{array}$ & References \\
\hline \multicolumn{6}{|l|}{ Air cushion vehicle } \\
\hline & 0.007 & - & - & - & Mellor 1980 \\
\hline Voyageur & $0.004-0.006$ & - & $0.3-0.75$ & $10-260$ & $\begin{array}{l}\text { U.S. Army 1982, } 1982 \\
\text { Robertson } 1975\end{array}$ \\
\hline ACT-100 & - & - & $0.3-0.7$ & - & U.S. Army 1982 \\
\hline \multicolumn{6}{|l|}{ Icebreaking vessels } \\
\hline & $0.1-1.7$ & - & - & - & Mellor 1980 \\
\hline & 0.2 & 1003 & $0.3-0.4$ & 3 & Van der Kley 1965 \\
\hline "Project 16" & - & 455 & 0.5 & $3-5$ & Tsykin 1970 \\
\hline Icebreaker & & & & & \\
\hline \multicolumn{6}{|l|}{ Blasting (submerged) } \\
\hline Chemical & $0.12-0.38$ & - & - & - & Mellor 1986 \\
\hline Chemical & - & $3,000^{*}$ & 0.5 & - & Labbé 1983 \\
\hline Chemical & - & $4,060+$ & - & - & Miner 1997 \\
\hline Chemical & - & $5,000^{* *}$ & 0.4 & $0.05+t$ & Van der Kley 1965 \\
\hline Compressed gas & 0.23 & & 0.3 & & Mellor 1980 \\
\hline \multicolumn{6}{|l|}{ Blasting (surface) } \\
\hline Chemical & - & $30,000^{* *}$ & 0.4 & $0.1+\dagger$ & Van der Kley 1965 \\
\hline \multicolumn{6}{|l|}{ Other } \\
\hline Amphibex $^{\mathrm{TM}}$ & 0.94 & 1,770 & $0.35-0.76$ & 0.16 & Haehnel et al. 1995 \\
\hline $\begin{array}{l}\text { AST-002 (continuous } \\
\text { breaking }\end{array}$ & - & - & 0.45 & $3-4$ & Edworthy et al. 1982 \\
\hline AST-002 & - & - & $0.45-0.6$ & $0.6-0.75$ & Edworthy et al. 1982 \\
\hline
\end{tabular}

${ }^{*}$ Cost brought forward to 1996 US \$ using Consumer Price Index. tUsing currency exchange rate for 1996, \$1.37 CAN = \$1 US.

**Using currency exchange rate for 1965, 3.6 guilders = \$1 US.

t+Estimated based on 4 men working to place and detonate charges.

Note: Using currency exchange rate for 1970,1 rouble $=\$ 1.10$. 
Table 5. Cost of dusting operations in 1996 U.S. dollars.

\begin{tabular}{|c|c|c|c|c|}
\hline Method & $\begin{array}{l}\text { Cost } \\
(\$ / h a)\end{array}$ & $\begin{array}{c}\text { Application } \\
\text { rate } \\
(h a / h r)\end{array}$ & Location & Reference \\
\hline Pumping & $4,000^{*}$ & 0.24 & Alaska & Moor and Watson 1971 \\
\hline Aerial Dusting & 8,200 & 1.4 & Galena, Alaska & Haehnel et al. 1996 \\
\hline $\begin{array}{l}\text { Hydroseeder using } \\
\text { cannon }\end{array}$ & 8,800 & 0.8 & $\begin{array}{l}\text { Montpelier and } \\
\text { White River, Vermont }\end{array}$ & Haehnel et al. 1996 \\
\hline $\begin{array}{l}\text { Hydroseeder using } \\
\text { extension hose }\end{array}$ & 12,000 & 0.4 & Montpelier, Vermont & Haehnel et al. 1996 \\
\hline Aerial Dusting & $21,000+$ & 0.8 & Platte River, Nebraska & $\begin{array}{c}\text { Haehnel et al. 1996, } \\
\text { U.S. Army } 1994\end{array}$ \\
\hline
\end{tabular}

*Price brought forward from 1971 using the CPI.

tPrice brought forward from 1993 using an inflation rate of 3\% per year.

of aerial dusting can vary by a factor of $2-3$. The low cost of dusting achieved at Galena is likely due to optimization resulting from 25 years of experience in dusting (Haehnel et al. 1996).

For comparison, the cost and performance data for these various methods shown in Tables $3-5$ are also presented in Figure 20. The application rate given in Figure 20 is the rate at which the ice surface is treated with the specified method. In the case of icebreaking, this application rate is also the ice destruction rate. However, for dusting ice, destruction is a process that takes place over several weeks following the application and depends on the prevailing weather conditions for any given location and year. Thus, determination of a destruction rate for dusting is not trivial and cannot be determined explicitly from the data presented in Table 5. For ice cutting, the applica-

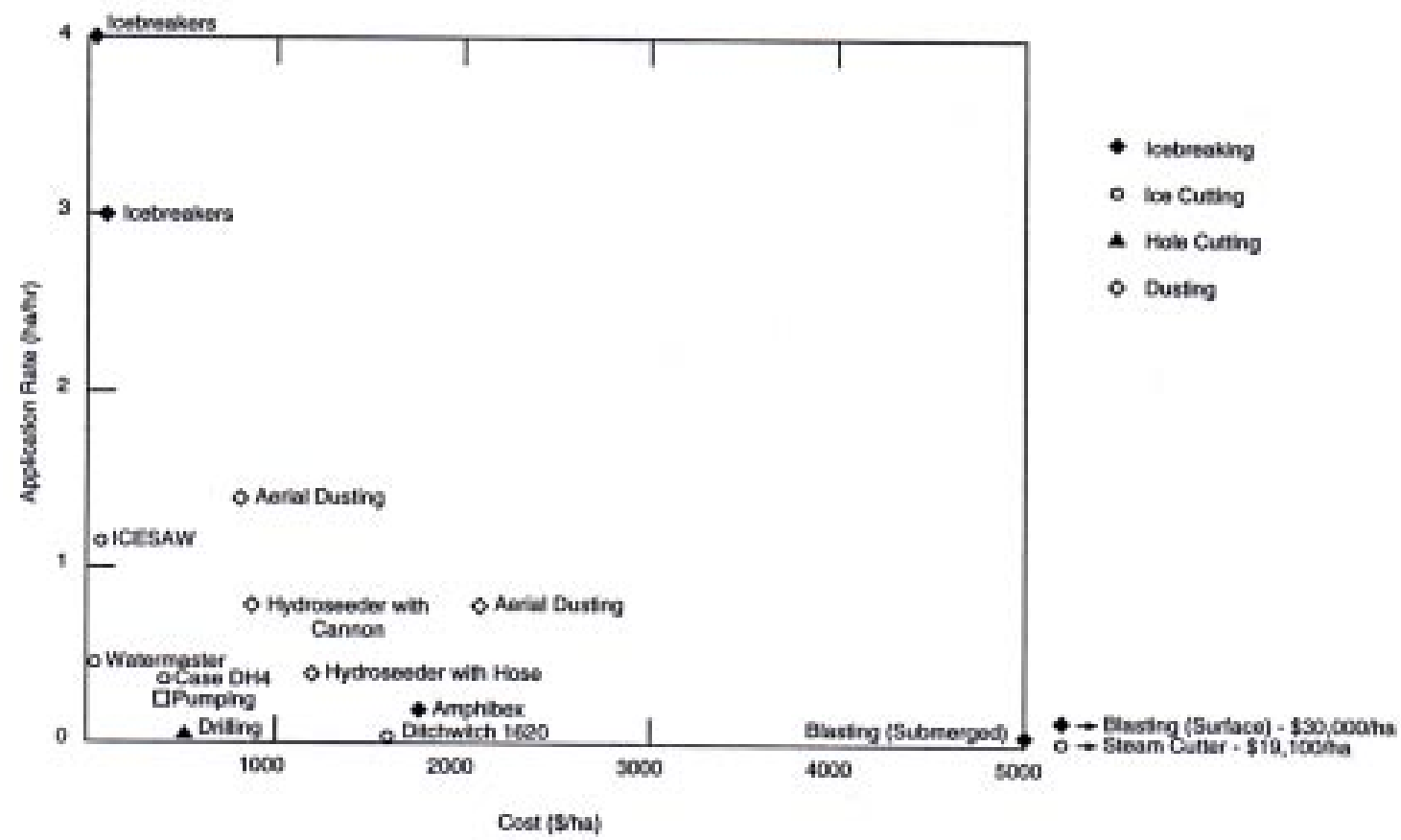

Figure 20. Cost and performance data for various methods of ice control. 
tion rate, and cost data presented in Figure 20 are based on cutting large sections* of an ice cover in the same fashion as pattern 1 shown in Figure 1b, with the herringbone pattern repeated every $15 \mathrm{~m}$. The ice was assumed to be $0.5 \mathrm{~m}$ thick.

Methods on the left and top of Figure 20 are the least costly to apply, while those on the lower right are the most costly in terms of both time and money. Clearly blasting is an expensive and slow method, while icebreakers are the quick and inexpensive. Many of the methods listed in Tables 3-5 did not have sufficient data to plot in Figure 20. One of the obvious omissions is air cushion vehicles, which perform far better on level ice than conventional icebreakers, yet there are not any cost data available.

\section{CASE STUDY}

In addition to providing a cost comparison, the information in Tables 3-5 can be used for planning ice cutting operations. For example, a proposed operation may require weakening a $600-\mathrm{m}-$ long stretch of river that is $36 \mathrm{~m}$ wide with an average ice thickness of $0.5 \mathrm{~m}$ (similar to the section of Beaurivage River weakened in 1982 and 1983). The time and cost required to accomplish this is estimated for three different methods: cutting, icebreaking, and dusting.

Ice cutting-For this operation the pattern would be cut about every $15 \mathrm{~m}$ apart with the lines making an angle of about $45^{\circ}$ with the bank (similar to pattern 1 in Fig. 1b). This would require about $1700 \mathrm{~m}$ of trenches to be cut. With a trencher equivalent to the Case DH4, the kerf width would be about $15 \mathrm{~cm}$ (Table 3), and the amount of ice removed would be $128 \mathrm{~m}^{3}$. With an average ice removal rate of $0.4 \mathrm{~m}^{3} / \mathrm{min}$ it would take approximately 5 hours to accomplish this with a single trencher, and cost about $\$ 2,900$ (including mobilization costs).

Icebreaking-If two-thirds of the channel width were to be opened, then the area of ice to break would be about 1.4 ha. The ice is proposed to be broken by blasting. From Table 4 the cost for blasting 1 ha is about $\$ 4,000$ on average, so this operation would cost about $\$ 5,600$ and take about 3.5

*By assuming that large ice section are being cut, the mobilization costs can be neglected since they are small in comparison to the overall cost of the operation. working days (time estimate based on four people setting and detonating charges).

Dusting-Again, the middle two-thirds of the channel will be weakened (about 1.4 ha). On a river as narrow as $36 \mathrm{~m}$, aerial dusting would be difficult to execute, so the hydroseeder would be selected for this operation. If there is not good access from the shore, the plan would be to use the hose extension to spread the dusting material, which gives a rate of application of 0.4 ha per hour. Thus, it would take about 3.5 hours to apply the material and cost about $\$ 1,700$. The final cost may be slightly higher, depending on the dusting material used. The values given in Table 5 are for applying leaf mulch.

The ice cutting and dusting operations cost about the same, and in both cases the time is about 1 working day. In comparison, the blasting operation costs almost 2-3 times more and takes 6-8 times as long to accomplish. As previously mentioned both blasting and cutting operations were carried out on $600 \mathrm{~m}$ of the Beaurivarge in 1982 and 1983; thus a direct comparison can be made between these estimated values and actual. The blasting operation carried out in 1982 cost about $\$ 6,000$ (in 1996 U.S. dollars). Similarly, the cost for cutting the same area was about $\$ 3,000$ and took about 8 hours. These figures agree well with the estimates of $\$ 5,800$ and $\$ 2,900$ for blasting and cutting, respectively.

In choosing any of the methods discussed in this case study, there are other factors that should be considered before final selection can be made, such as

- Effects of blasting on adjacent properties.

- Environmental impacts of dusting or blasting.

- Air temperature and available sunlight preceding breakup if dusting is to be used.

- Bearing capacity of the ice if equipment or personnel are going to be placed on the ice for any of these methods.

This sections provides a basic estimate of the cost of nonstructural operations, both in terms of time and money, yet there has been no mention of the relative effectiveness of these methods to reduce the frequency and severity of ice jams. The reason for this omission is there is little available guidance that will allow prediction of ice jam potential based on ice strength, piece size, etc. Short of removing the ice cover from the entire river, there is no guarantee that any of these methods 
will prevent ice jam formation. To illustrate, during the 25 years of dusting the Yukon River at Galena, Alaska, there were several years that ice jams did form and cause flooding. However, according to Bird* the frequency and severity of the flooding was reduced in comparison to pre-dusting years.

There are some trends that can be gleaned from the collective experience in application of nonstructural ice control methods:

- Reduction in ice volume in the river reduces ice jam potential,

- Weakening the ice cover appears to reduce ice jam frequency and severity,

- Smaller ice pieces reduce the potential for ice jams to occur.

Using these as a general guide will aid in selection of nonstructural ice control methods.

\section{CONCLUSIONS}

The foregoing presents a multitude of nonstructural measures that can be employed to reduce the risk of ice jam formation. Where possible, the effectiveness of these methods has been assessed. In terms of development, some of these are still in their infancy, while others are well advanced in terms of available guidance and field experience. Destruction of an ice cover by blasting falls into this latter category. This technique has been used successfully to both prevent ice jam formation and break existing jams. However, there is little guidance currently available to predict the reduction in ice jam potential due to application of any of these measures. All that is clearly known is that the complete removal of ice from the river will eliminate the possibility of ice jam formation. Beyond this, theoretical or empirical relations that predict the marginal reduction of jam potential by weakening the ice (e.g., dusting) or reducing floe size (e.g., advance cutting of the cover) are not well developed. Further work in this area should focus on developing governing relationships that relate ice and river properties and meteorological conditions to ice jam potential and severity. Pertinent ice properties include ice cover thickness, spatial extent, strength, volume and piece size.

*Personal communication, M. Bird, Alaska Division of Emergency Services, Fort Richardson, Alaska, 1994.
River characteristics of concern are channel morphology, water surface slope, water velocity, discharge, and typical breakup hydrographs.

Nonstructural methods may be used to extend the operating envelope of structural measures or to play a role in an ice control strategy that uses both structural and nonstructural components to provide the desired results. Future work will explore this possibility.

\section{LITERATURE CITED}

Aleinikov, S.M., V.A. Koreníkov, and G.A. Morozov (1974) Ice-cutting operations in river ice control. In Proceedings IAHR-PIANC International Symposium on River and Ice, Budapest, Hungary, pp. 109-114.

Alexbow Ltd. (1967) Alexbow ice breaking forms: Report on trials and developments to March 1967. Gilmore, German \& Milne, Montreal, Quebec.

Andersen, P.F., and N.F.B. Allyn (1984) Ice management for Beaufort sea production harbours. In Proceedings IAHR Symposium, Hamburg, Germany.

Antrushin, N.S. (1965) Aviation-chemical methods of accelerating the thawing of ice. In Trudy Koordinatsionnykh Soveshchaniy po Gidrotekhnike (Transactions of the Coordinating Conference on Hydraulic Engineering) no. 17, pp. 219-224.

Arnold, K.C. (1961) An investigation into methods of accelerating the melting of ice and snow by artificial dusting: Geology of the Arctic. In Proceedings of the First International Symposium on Arctic Geology, January 11-13, 1960, Calgary, Alberta, Canada, Vol. II, Toronto, University of Toronto Press, pp. 989-1013.

Ashton, G.D. (1979) Suppression of river ice by thermal effluents. USA Cold Regions Research and Engineering Laboratory, CRREL Report 79-30.

Ashton, G. D. (1982) Theory of thermal control and prevention of ice in rivers and lakes. Advances in Hydroscience, 13: 131-185.

Ashton, G. D. (1985) Deterioration of floating ice covers. Journal of Energy Resources Technology, 107: 177-182.

Ashton, G.D., Ed. (1986) River and Lake Ice Engineering. Littleton, Colorado: Water Resources Publications.

Ashton, G.D, S.L. DenHarthog, and B. Hanomoto (1973) Ice breaking by tow on the Mississippi River. USA Cold Regions Research and Engineering Laboratory, Special Report 192.

Belore, H.S., B.C. Burrell, and S. Beltaos (1990) 
Ice jam mitigation. Canadian Journal of Civil Engineering, 17: 675-685.

Billfalk, L. (1984) Strategic hydro power operation at freeze-up reduces ice jamming. In Proceedings of the IAHR Ice Symposium, Aug. 27-31, Hamburg, Germany, Vol. 1, pp. 265-275.

Bojun, A., and S. Si (1990) A way of preventing structures from damage due to ice pressures. In Proceedings of IAHR 10th International Symposium on Ice, 20-23 Aug., Espoo, Finland, pp. 858-863.

Bolsenga, S.J. (1968) River ice jams, a literature review. Research Report 5-5, U.S. Army Corps of Engineers Lake Survey District, Great Lakes Research Center, Detroit, Michigan.

Bonetti, J. (1989) Trip Report: 29-31 March 1989, Oconto River ice jam, Oconto, WI, CENCE-COKF, 23 May.

Bonin, J.H., and O.E.Teichmann (1949) Investigation of solar energy for ice melting. Armour Research Foundation, Technology Center, Final Report, Project No. 90-688 D.

Calkins, D., and M. Mellor (1976) Investigation of water jets for lock wall deicing. In Proceedings of Third International Symposium on Jet Cutting Technology, 11-13 May, Chicago, Illinois, pp. G2-13-G2-22.

Cavan, B.P. (1969) A literature review of dusting technology and deicing. Research Report 5-7, U.S. Army Corps of Engineers Lake Survey District, Detroit, Michigan.

Colbeck, S.C. (1988) Snowmelt increase through albedo reduction. USA Cold Regions Research and Engineering Laboratory, Special Report 88-26.

Cook, G.R., and M.D. Wade, Jr. (1968) Successful ice dusting at Fairbanks, Alaska, 1966. Journal of the Hydraulics Division, Proceedings of the ASCE, HY 1, January, pp. 31-41.

Coutermarsh, B.A. (1989) Factors affecting rates of ice cutting with a chain saw. USA Cold Regions Research and Engineering Laboratory, Special Report 89-24.

Daly, S.F. (1997) Trip report. USA Cold Regions Research and Engineering Laboratory, Hanover, New Hampshire, 4 February (unpublished).

Deck, D. (1986) Kankakee River ice jam flooding. Report prepared for the U.S. Army Engineer District, Chicago, June.

DenHartog, S.L., and G.E. Gooch (1989) Trip report: Oconto, WI. USA Cold Regions Research and Engineering Laboratory, Hanover, New Hampshire, 6 April (unpublished).

Deugo, D. (1973) Ice control on the Rideau River, Ottawa. Seminar on Ice Jams in Canada, Alberta, Canada. Technical Memorandum no. 107, pp. 155157.
Edworthy, J., L. Chabot, and D.R. Miller (1982) Evaluation of Archimedean screw tractor for ice management. Arctec Canada Limited, Project No. 4582/4583, Calgary, Alberta, Canada.

Echert, D.C.S., and J.J. Kollé (1986) An ice penetration drill/anchor using ultrahigh-pressure waterjets. In Second Workshop on Ice Penetration Technology, 16-19 June, Monterey, Cal., USA Cold Regions Research and Engineering Laboratory, Special Report 86-30.

Francois, R.E. (1984) Field experiences with thermal drilling in sea ice. In Workshop on Ice Penetration Technology, 12-13 June, Hanover, N.H. USACold Regions Research and Engineering Laboratory, Special Report 84-33.

Frankenstein, G.E., and N. Smith (1966) Operation breakup, FY 66: Engineering properties and crater hole measurements. Technical Note, April, U.S. Army Materiel Command. USA Cold Regions Research and Engineering Laboratory (unpublished).

Garfield, D.E., B. Hanamoto, and M. Mellor (1976) Development of large ice saws. USA Cold Regions Research and Engineering Laboratory, CRREL Report 76-47.

Gooch, G., and D. Deck (undated) Kankakee River siphon performance. USA Cold Regions Research and Engineering Laboratory (unpublished).

Haehnel, R.B. (1996) Drilling holes in ice to reduce ice jam potential. Ice Engineering Information Exchange Bulletin, no. 14, U.S. Army Cold Regions Research and Engineering Laboratory, Hanover, New Hampshire.

Haehnel, R.B., C.H. Clark, and S. Taylor (1996) Dusting river ice with leaf mulch to aid in ice deterioration. USA Cold Regions Research and Engineering Laboratory, Special Report 96-7.

Haehnel, R.B., H.D. Haynes, and C.H. Clark (1995) Breaking river ice to prevent ice jams. USA Cold Regions Research and Engineering Laboratory, Ice Engineering Information Exchange Bulletin, no. 11.

Hinchley, M.J., C.H. Mak, and D.B. Colbourne (1991) Ice tank tests on circular and sidewall air cushion ice breaker bows. In Proceedings, 10th OMAE, June 23-28, Stavanger, Norway, Vol. IV.

Hindley, M. (1996) Fake waves break ice in the winter. New Scientist, 151(2043): 23.

Jolicoeur, L., B. Michel, and J. Labbé (1984) Cutting trenches in an ice cover to prevent ice jams. In Workshop on the Hydraulics of River Ice, June 2021, Fredricton, New Brunswick, Canada, pp. 127-139. 
Kurtz, M.K., , R.H., Benfer, , W.G. Christopher, , G.E. Frankenstein, G. Van Wyhe, and A.E. Roguski (1966) Consolidated report, Operation Break-up, FY66, ice cratering experiment, Blair Lake, Alaska, NCG/TM 66-7, U.S. Army Nuclear Cratering Group, Lawrence, Radiation Laboratory, University of California, Livermore.

Labbé, J. (1983) Decoupage de la glace: Mesure preventive contre la formation d'embacles, Riviere Beaurivage (Cutting ice to prevent ice jams on the Beaurivage River). Ministry of Environment, Quebec, Canada.

Lewis, J.W., N.A. Ehrlich, and E.V. Lecourt (1973) Development of a craft capable of preparing an ice-free channel through solid ice cover. In Proceedings, 2nd International Conference on Port and Ocean Engineering under Arctic Conditions (POAC), University of Iceland, 27-30 Aug., Reykjavik, Iceland, pp. 138-161.

Mellor, M. (1980) Icebreaking concepts. USA Cold Regions Research and Engineering Laboratory, Special Report 80-2.

Mellor, M. (1984) A shopper's guide to ice penetration. In Workshop on Ice Penetration Technology, 12-13 June, Hanover, NH, CRREL Special Report 8433, U.S. Army Cold Regions Research and Engineering Laboratory, Hanover, NH, pp. 1-35.

Mellor, M. (1986) Revised guidelines for blasting floating ice. USA Cold Regions Research and Engineering Laboratory, Special Report 86-10.

Mellor, M., and A. Kovacs (1972) Breakage of floating ice by compressed gas blasting. USA Cold Regions Research and Engineering Laboratory, Special Report 184.

Michel, B. (1971) Winter regime of rivers and lakes. USA Cold Regions Research and Engineering Laboratory, Monograph 111-B1a.

Michel, B. (1984) Ice engineering in 1984. In Proceedings of IAHR Ice Symposium 1984, Hamburg, Germany, pp. 301-325.

Moor, J.H., and C.R. Watson (1971) Field tests of ice jam prevention techniques. Journal of the Hydraulics Division, Proceedings of the ASCE, HY6, June, pp. 777-789.

Oconto County Reporter (1952) To cut flood threat. 20 March 1952, Oconto, Wisconsin.

Paily, P.P, , E.O. Macagno, and J.F. Kennedy (1974) Winter-regime thermal response of heated streams. ASCE Journal of Hydraulics Division, HY4, April, pp. 531-551.

Prowse, T.D., and M.N. Demuth (1992) Spatial and temporal variability of river ice-cover strength. In Proceedings 9th International Northern Research Basins Symposium/Workshop, NHRI Sym- posium No. 10, Canada, pp. 405-421.

Prowse, T.D., M.N. Demuth, and H.A.M. Chew (1990a) Changes of flexural strength of ice under radiation decay. Nordic Hydrology, 21: 341-354.

Prowse, T.D., M.N. Demuth, and H.A.M. Chew (1990b) The deterioration of freshwater ice due to radiation decay. Journal of Hydraulic Research, 28: 685-697.

Robertson, B.W. (1975) Winter and icebreaking evaluation of CCG Voyageur CH-CGA. Canadian Coast Guard Report, Montreal, Canada.

Spetsov, F.A. (1965) Weakening of ice in spring season by darkening its surface. In Trudy Koordinatsionnykh Soveshchaniy po Gidrotekhnike (Transactions of the Coordinating Conference on Hydraulic Engineering), no. 17, pp. 225-235.

Spetsov, F.A., and I.N. Shatalina (1965) Experience gained in applying chemicals for weakening the strength of an ice cover. In Trudy Koordinatsionnykh Soveshchaniy po Gidrotekhnike (Transactions of the Coordinating Conference on Hydraulic Engineering), no. 17, pp. 212-218.

Slaughter, C.W. (1969) Snow albedo modification: A review of literature. USA Cold Regions Research and Engineering Laboratory, Technical Report 217. Sodhi, D.S. (1995) Northern Sea Route reconnaissance study: A summary of ice breaking technology. USA Cold Regions Research and Engineering Laboratory, Special Report 95-17.

Tatinclaux, J.P., and C.R. Martinson (1988) Development of a river ice prow. USA Cold Regions Research and Engineering Laboratory, CRREL Report 88-9.

Tuthill, A.M. (1996) Memorandum for Record. US Army Cold Regions Research and Engineering Laboratory, Hanover, New Hampshire, 20 May (unpublished).

Tsykin, E.N. (1970) Use of the ice channeling plow for the prevention of ice barrages. Izvestiya Akadeniyi Nauk SSSR, Geographical Series, 3: 61-66. Tsykin, E.N. (1982) Some new methods of ice destruction for the control of jams in backwater areas of hydro-power stations. In Proceedings, Canadian Society for Civil Engineering, May 27-28, Edmonton, Alberta, Canada, pp. 12071219.

U.S. Army Corps of Engineers (1968) Operation Dusty Alaska. Alaska District.

U.S. Army Corps of Engineers (1979) Platte River, Nebraska: 1979 ice dusting. Omaha District, Missouri River Division, March.

U.S. Army Corps of Engineers (1982) Ice Engineering. Engineer Manual no. 110-2-1612.

U.S. Army Corps of Engineers (1994) Ice dusting 
of the Platte River: 1994, Omaha District, Missouri River Division, September.

Van der Kley, I.J. (1965) The use of explosives for clearing ice. Rijkswaterstaat Communications, no. 7, The Hague, Netherlands.

Wade, M.D., Jr. (1966) Operation Peggy: Cratering experiments 1966. U.S. Army Engineer District, Alaska, Corps of Engineers.

Wake, A., and R.R. Rumer (1979) Effect of surface meltwater accumulation on the dissipation of lake ice. Water Resources Research, 15(2).

White, K.D., and R.L. Kay (1997) Practitioner's
Forum: Is blasting of ice jams an effective mitigation strategy? ASCE Journal of Cold Regions Engineering, II(3): 171-179..

Williams, G.P. (1976) Ice dusting experiments to increase the rate of melting of ice. Technical Paper No. 239, National Research Council, Ottawa, Canada, January.

Williams, G.P., and L.W. Gold (1963) The use of dust to advance the break-up of ice on lakes and rivers. In Proceedings of the 1963 Annual Meeting of the Eastern Snow Conference, Quebec City, Quebec, Canada, pp. 31-56. 


\section{REPORT DOCUMENTATION PAGE}

Public reporting burden for this collection of information is estimated to average 1 hour per response, including the time for reviewing instructions, searching existing data sources, gathering and maintaining the data needed, and completing and reviewing the collection of information. Send comments regarding this burden estimate or any other aspect of this collection of information, including suggestion for reducing this burden, to Washington Headquarters Services, Directorate for Information Operations and Reports, 1215 Jefferson Davis Highway, Suite 1204, Arlington, VA 22202-4302, and to the Office of Management and Budget, Paperwork Reduction Project (0704-0188), Washington, DC 20503.

\begin{tabular}{|l|l|l|}
\hline $\begin{array}{l}\text { 1. AGENCY USE ONLY (Leave blank) } \\
\text { 2. REPORT DATE } \\
\text { December 1998 }\end{array}$ & 3. REPORT TYPE AND DATES COVERED \\
\hline $\begin{array}{l}\text { 4. TITLE AND SUBTITLE } \\
\text { Nonstructural Ice Control }\end{array}$ & 5. FUNDING NUMBERS
\end{tabular}

CWIS 33137

\section{AUTHORS}

Robert B. Haehnel

7. PERFORMING ORGANIZATION NAME(S) AND ADDRESS(ES)

8. PERFORMING ORGANIZATION

REPORT NUMBER

U.S. Army Cold Regions Research and Engineering Laboratory

72 Lyme Road

Special Report 98-14

Hanover, New Hampshire 03755

9. SPONSORING/MONITORING AGENCY NAME(S) AND ADDRESS(ES)

10. SPONSORING/MONITORING

AGENCY REPORT NUMBER

Office of the Chief of Engineers

Washington, D.C. 20314-1000

\section{SUPPLEMENTARY NOTES}

For conversion of SI units to non-SI units of measurement, consult ASTM Standard E380-93, Standard Practice for Use of the International System of Units, published by the American Society for Testing and Materials, 100 Barr Harbor Drive, West Conshohocken, Pa. $19428-2959$.

12a. DISTRIBUTION/AVAILABILITY STATEMENT

12b. DISTRIBUTION CODE

Approved for public release; distribution is unlimited.

Available from NTIS, Springfield, Virginia 22161

\section{ABSTRACT (Maximum 200 words)}

Nonstructural ice control measures are used for reducing the frequency and severity of ice jam damages that do not rely on the use of a structure placed in the river. This report is a comprehensive review of current nonstructural ice control methods in use. Both advance measures and emergency response methods are addressed. Where possible, the effectiveness of these methods has been assessed, and cost of application has been tabulated. In terms of development, some of these are still in their infancy, while others are well advanced in terms of available guidance and field experience. Nonstructural methods can be used to extend the operating envelope of structural measures and can play a role in an ice control strategy that uses both structural and nonstructural components to provide the desired results. There is little guidance currently available to predict the reduction in ice jam potential due to application of any of these measures. Further work in this area should focus on developing governing relationships that relate ice and river properties and meteorological conditions to ice jam potential and severity.

\begin{tabular}{|c|c|c|c|c|c|}
\hline \multirow[t]{2}{*}{ 14. SUBJECT TERMS } & \multirow{2}{*}{\multicolumn{2}{|c|}{$\begin{array}{l}\text { Explosives } \\
\text { Freshwater ice } \\
\text { Icebreakers }\end{array}$}} & \multirow{2}{*}{$\begin{array}{l}\text { Ice control } \\
\text { Ice jams } \\
\text { Ice saws }\end{array}$} & \multirow[t]{2}{*}{ Rivers } & $\begin{array}{l}\text { 15. NUMBER OF PAGES } \\
44\end{array}$ \\
\hline & & & & & 16. PRICE CODE \\
\hline \multirow{2}{*}{\multicolumn{2}{|c|}{$\begin{array}{l}\text { 17. SECURITY CLASSIFICATION } \\
\text { OF REPORT } \\
\text { UNCLASSIFIED }\end{array}$}} & & $\begin{array}{l}\text { CLASSIFICATION } \\
\text { GE }\end{array}$ & $\begin{array}{l}\text { 19. SECURITY CLASSIFICATION } \\
\text { OF ABSTRACT }\end{array}$ & 20. LIMITATION OF ABSTRACT \\
\hline & & & ASSIFIED & UNCLASSIFIED & UL \\
\hline
\end{tabular}

